\title{
A Survey of Educational Program Needs for the Florida Association of Counties County Commissioner Training Program
}

\author{
Rodney L. Clouser
}

\section{INTRODUCTION}

Florida Cooperative Extension has partnered with the Florida Association of Counties (FAC) and the Florida Counties Foundation (FCF) since 1998 in surveying Florida County Commissioners and County Administrators approximately every two years. The survey collects information regarding attendance at FAC-FCF sponsored events, willingness to pay for educational programs, worth of events and programs attended by commissioners and administrators, desired locations for educational activities and, most importantly, the type and amount of training needed by commissioners on various topics that would assist them as an elected policy maker.

The results of the 2005-06 survey are presented as an executive summary that follows. In addition, for the first time the executive summary, survey questionnaire and PowerPoint presentation of results are being made available via a link for those who would like to view or print the entire document.

\section{UF $\mid$ FLORERIDA \\ IFAS Extension}

The Institute of Food and Agricultural Sciences (IFAS) is an Equal Opportunity Institution authorized to provide research, educational information, and other services only to individuals and institutions that function with non-discrimination with respect to race, creed, color, religion, age, disability, sex, sexual orientation, marital status, national origin, political opinions, or affiliations. U.S. Department of Agriculture, Cooperative Extension Service, University of Florida, IFAS, Florida A\&M University Cooperative Extension Program, and Boards of County Commissioners. Millie Ferrer-Chancy, Interim Dean 


\title{
A Survey of Educational Program Needs for the Florida Association of Counties County Commissioner Training Program
}

\author{
Rodney L. Clouser ${ }^{1}$
}

\section{EXECUTIVE SUMMARY}

\section{County Commissioner and County Administrator Educational Survey}

1. The survey response rate was large. A total of 250 surveys or 56.3 percent of all surveys were returned. The usable survey response rate was 55.4 percent (246 total surveys).

2. Almost three of every four commissioners ( 73 percent) who responded to the survey had been in office eight years or less.

3. Eighty-five percent of commissioners and administrators responding to the survey were from counties with a population less than 500,000.

4. Ninety-four commissioners or 48 percent of commissioner respondents to the survey are CCC (Certified County Commissioners) graduates.

5. Seventy-six percent of CCC graduates (some have not graduated yet) indicated they were interested in some type of postgraduate CCC curriculum and 71 percent of them would prefer a policy-based postgraduate curriculum.

6. Only thirty-eight percent of respondents support use of nationally or professionally recognized speakers if it would double the registration price of $\mathrm{CCC}$ events.

7. Survey respondents are open to use of technology in securing a maximum of six hours of credit towards certification: 75 percent would be likely to use web-based classes, 67 percent would be likely to participate in streaming video classes, 30 percent would be likely to participate in real time distance education classes and 40 percent would be likely to participate by use of taped (DVD, VCR) classes. There was little support (17 percent) for phone conference classes coupled with computer graphics.

8. More than six in ten respondents support authorization of computer-based classes for CCC credit.

\footnotetext{
${ }^{1}$ Professor and Extension Public Policy Specialist, University of Florida, Florida/IFAS Cooperative Extension, Food and Resource Economics
} 
9. The overall top-voted training topics in the policy and procedure area were growth management, land use planning and zoning, alternative revenues, economic development, strategic planning and community visioning and natural resources issues related to water and land use. The top training topics in the people and personal area were strategic thinking and planning, leadership skills, developing a policy framework, conflict resolution and listening skills.

10. When asked to rank only the three top training topics the most requested topics in the policy and procedure area were growth management, budget and financial management, alternative revenues, land use planning and zoning and strategic planning and community visioning. The most requested training topics in the people and personal area were leadership skills, strategic thinking and planning, developing a policy framework, constituent services and conflict resolution skills.

11. Preference for workshop locations in rank order is Orlando, Tallahassee, Tampa, Gainesville, West Palm Beach and Jacksonville.

\section{SUMMARY}

Participation and returns of surveys by county commissioners and county administrators are at high levels. Prior to University of Florida Cooperative Extension becoming involved with the survey in 1998 the typical response rate was about 15 percent. In 1998, the survey response rate increased to 32 percent and, in 2002, the response rate was over 56 percent. Survey respondents indicated support for receiving some educational training through use of technology rather than at a location specific site.

From an educational standpoint, the most important education needs of those serving as county commissioners or administrators are:

$>$ Policy and procedure topic areas: growth management, land use planning and zoning, alternative revenues, economic development, strategic planning and community visioning and natural resources issues related to water and land use.

> People and personal topic areas: strategic thinking and planning, leadership skills, developing a policy framework, conflict resolution and listening skills. 


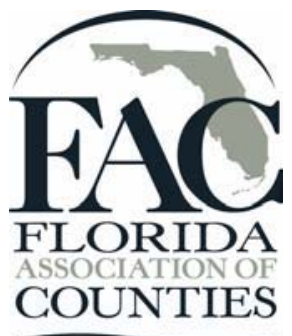

\section{UF $\mid$ FLIORIDPA \\ IFAS Extension}

All About Florida

1. How long have you been a county commissioner?
2 years or less
2 to 8 years
9 to 12 years
More than 12 years

2. What is the population of your county: $\square 75,000$ or less

75,001 to 499,000

Over 500,000

3. How often do you attend FAC events each year? $\quad \square$ Often $\quad \square$ Occasionally $\quad \square$ Rarely $\quad \square$ Never

4. Have you attended any County Commissioners Certification (CCC) courses in the past? $\square$ Yes $\square$ No

5. If so, rate their value to you in your job: (check one)

$\square$ Always useful $\quad \square$ Never useful $\quad \square$ Sometimes useful $\quad \square$ No opinion

6. Of the following locations for CCC workshops, which would you prefer most? (check one)

$\square$ Orlando/Orange County

$\square$ Tallahassee/ Leon County

$\square$ Gainesville/ Alachua County $\square$ Tampa/ Hillsborough County

$\square$ Jacksonville/ Duval County

$\square$ West Palm Beach/ Palm Beach County

7. Are you a CCC graduate: $\square$ Yes $\square$ No

8. If yes, would you be interested in continuing in an "post graduate" curriculum? $\square$ Yes $\square$ No

9. If yes, would you prefer that the "post graduate" curriculum be: (check one)

A skills building program which addresses topics such as leadership development, conflict resolution, communications skills, or other practical skills useful to commissioners; OR,

A policy issues approach addressing such topics as growth management, public finance, budgeting, environmental issues, or other policy issues? 
10. Would you be interested in including site visits to other counties as part of the "post graduate" program?
Yes
$\square$ No
Not sure

11. Would you support utilizing nationally recognized or professional speakers in the CCC programs even if the registration fees doubled from $\$ 125$ to $\$ 250$ ? $\quad \square$ Yes $\quad \square$ No $\quad \square$ Not sure

12. What is the best method for sending you information about education events or other FAC programs?

$\square$ Email $\quad \square$ US Mail $\quad \square$ Fax

13. In recent years, new technology has become available to do CCC training in different formats. If a maximum of 6 hours CCC training could be secured by using technology, how likely would you be to participate using the following technology?

a. Web based computer technology (written material with short tests):
$\square$ Very Likely
$\square$ Likely
$\square$ Somewhat Likely
$\square$ Unlikely
Not at all

b. Streaming video computer technology (like watching a TV show on your computer):

$\square$ Very Likely $\square$ Likely $\quad \square$ Somewhat Likely $\quad \square$ Unlikely $\quad \square$ Not at all

c. Live real time training from a distant site (a teacher at a distant site broadcasting live):

$\square$ Very Likely $\quad \square$ Likely $\quad \square$ Somewhat Likely $\quad \square$ Unlikely $\quad \square$ Not at all

d. Taped (DVD, VCR) training at a specific site in your county:
$\square$ Very Likely
$\square$ Likely
$\square$ Somewhat Likely
Unlikely $\quad \square$ Not at all

e. Phone conference coupled with computer based graphics :
$\square$ Very Likely
$\square$ Likely
$\square$ Somewhat Likely
$\square$ Unlikely $\quad \square$ Not at all

14. Would you support authorizing CCC credit for taking the computer based classes?

$\square$ Yes $\quad \square$ No $\quad \square$ No preference

15. Would you prefer a commissioners' education program that provided computer based courses?

$\square$ Yes $\square$ No

Comments on any of the previous items: 
16. What amount of training do commissioners need on the following Policy and Procedure topics to do their job better? (circle a number for each topic)

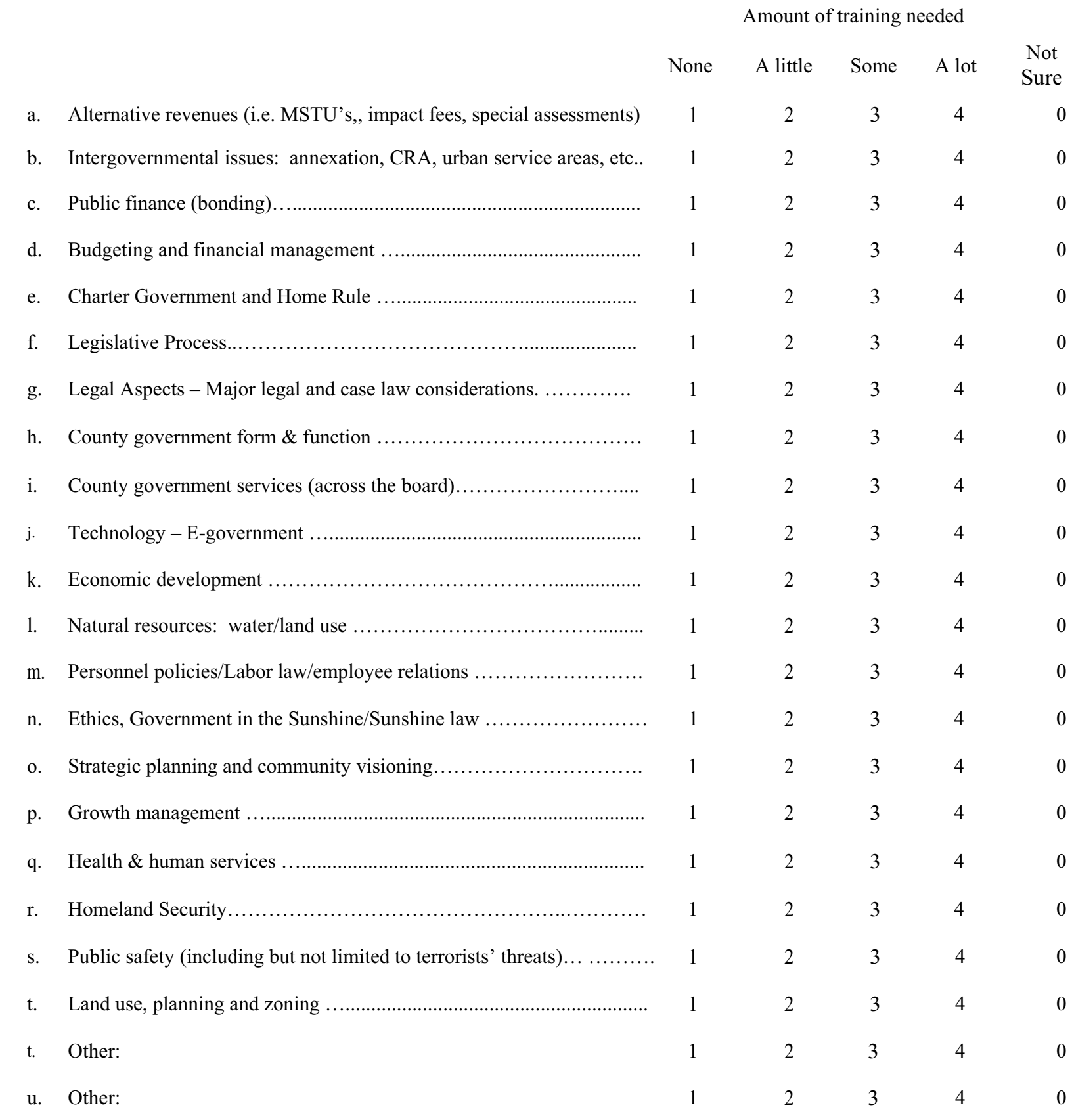

17. Of the topics listed in question 16, which are the most important to helping Commissioners do a better job? (please identify by alphabetical character the top 3 training needs) 
18. What amount of training do Commissioners need on the following Personal skills to do their job better? (circle a number for each topic)

Amount of training needed
a. Leadership skills.
b. Conflict resolution

\section{2}

34
0
c. Constituent relations ..

23
4
d. Customer service ..

$2 \quad 3 \quad 4$
e. Strategic thinking and planning.......
f. Diversity training..
g. Stress management .
h. Time management; balance work and home life.
1. Listening skills
J. Media/Presentation skills
k. Negotiating skills
1. Developing a Policy Framework (issues, alternatives, consequences)
m. Team Building.
n. Computer skills useful to commissioners.
o. Other:
p. Other:

\section{1}

$2 \quad 3 \quad 4$

None

A littl

Som

A lot

Not

Sure

19 Of the topics listed in question 18, which are the most important to helping Commissioners do a better job? (please identify by alphabetical character the top 3 training needs)

Most Important

$2^{\text {nd }}$ Most Important $3^{\text {rd }}$ Most Important

\section{PLEASE RETURN SURVEY TO IFAS FOR RECEIPT NO LATER THAN JANUARY 6, 2006. USE THE ENCLOSED ENVELOPE OR FAX TO THE FAC OFFICE AT (850) 488-7752.}

THANK YOU FOR YOUR ASSISTANCE. 


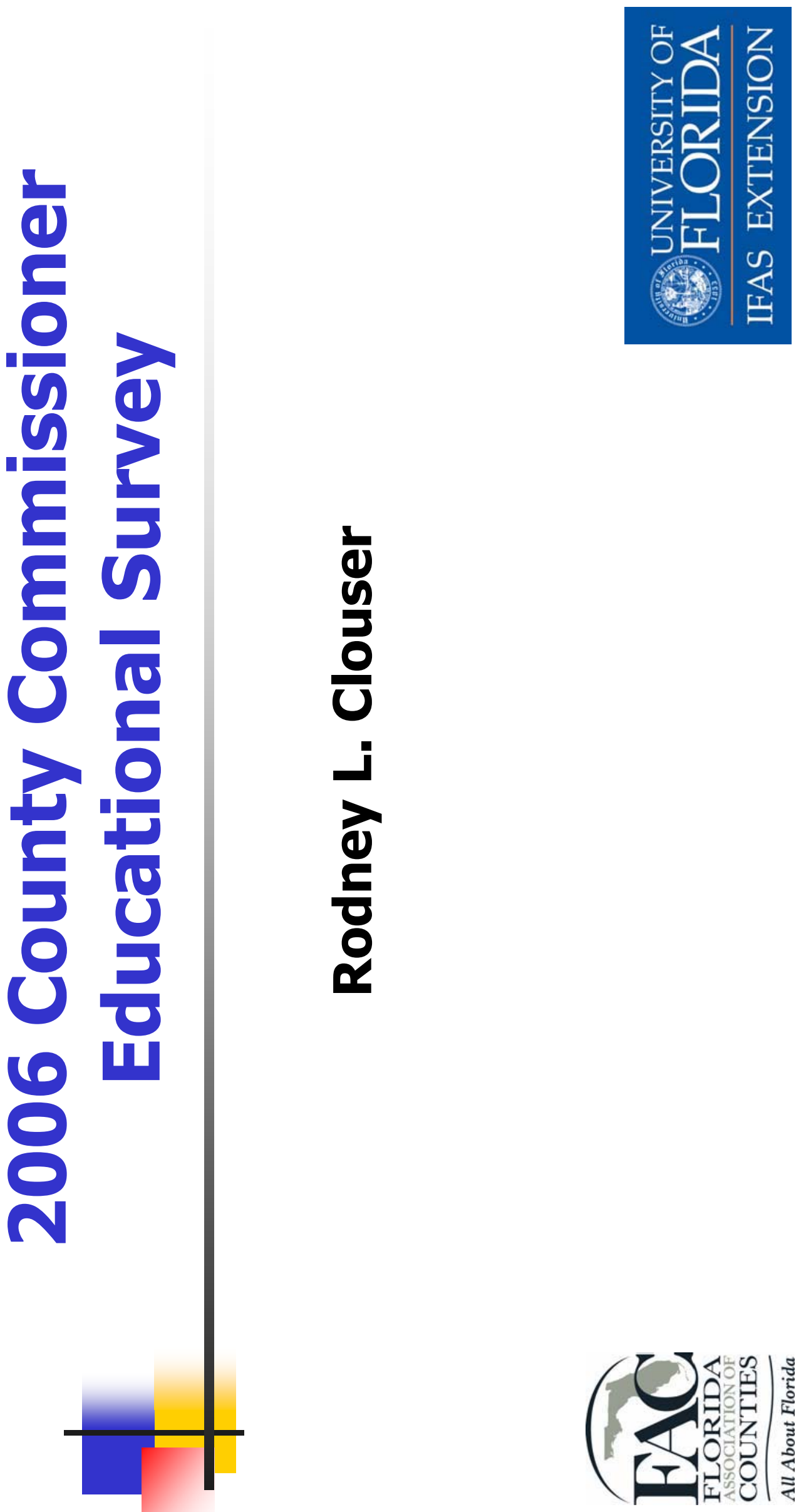



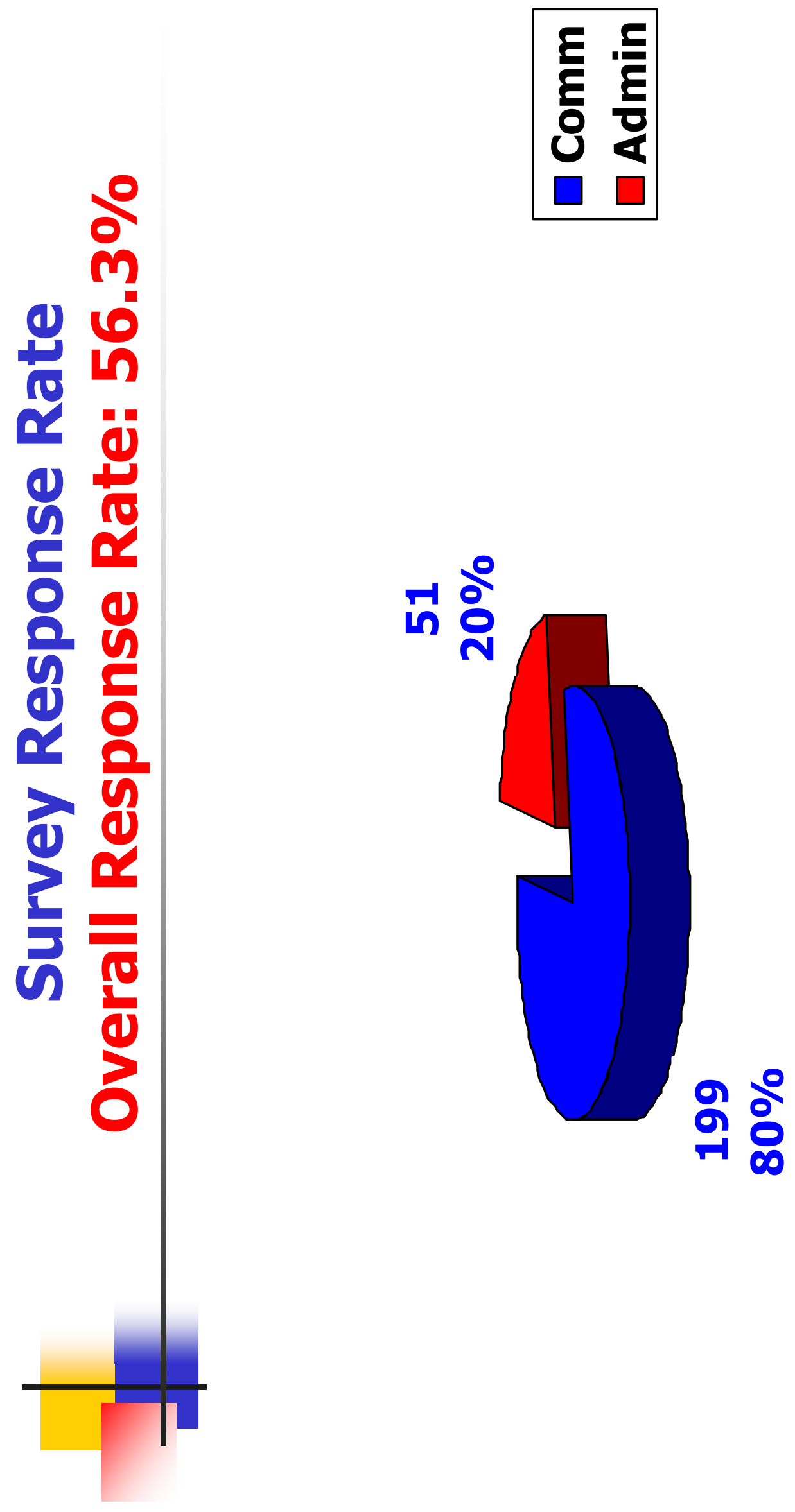

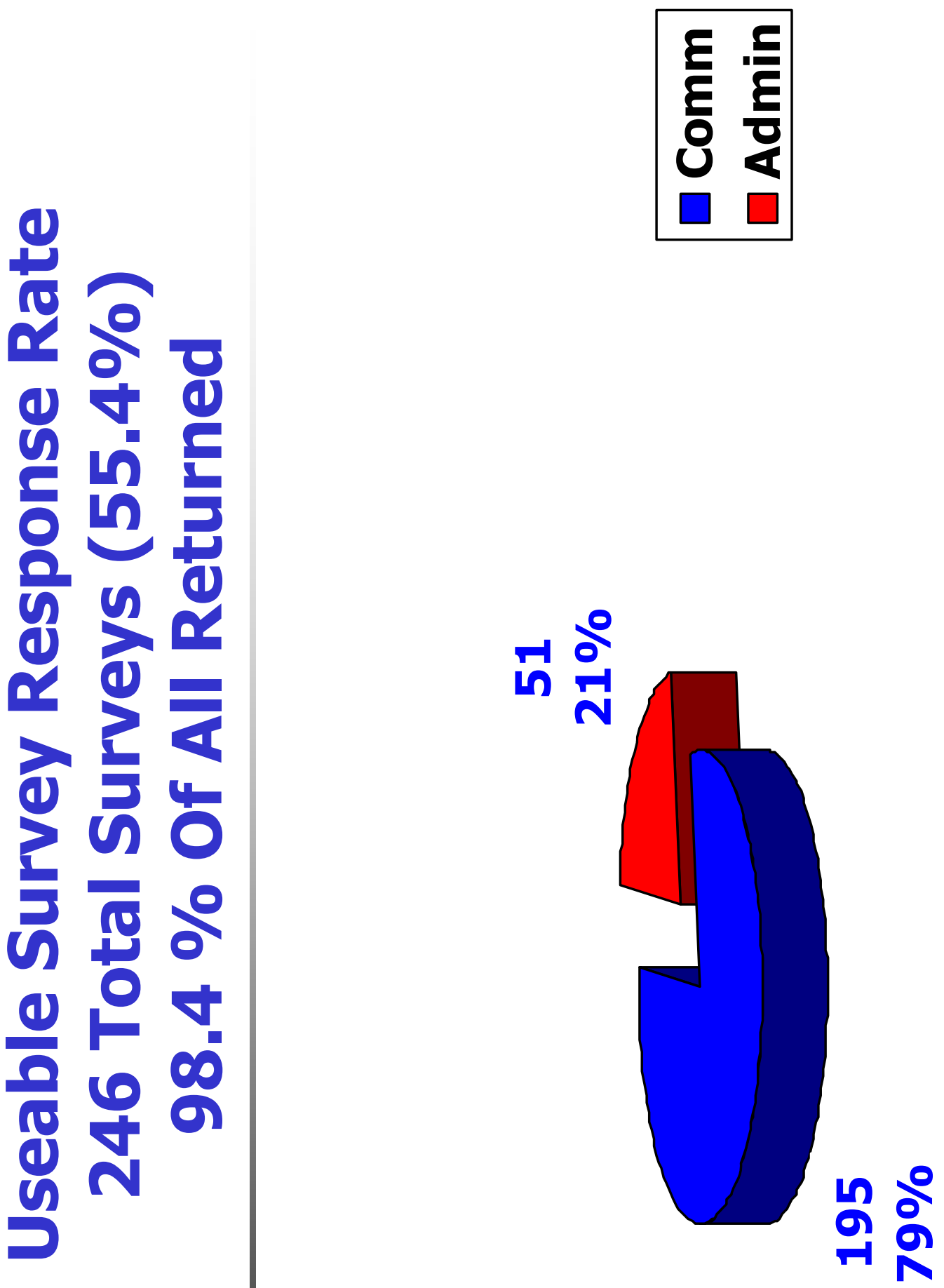

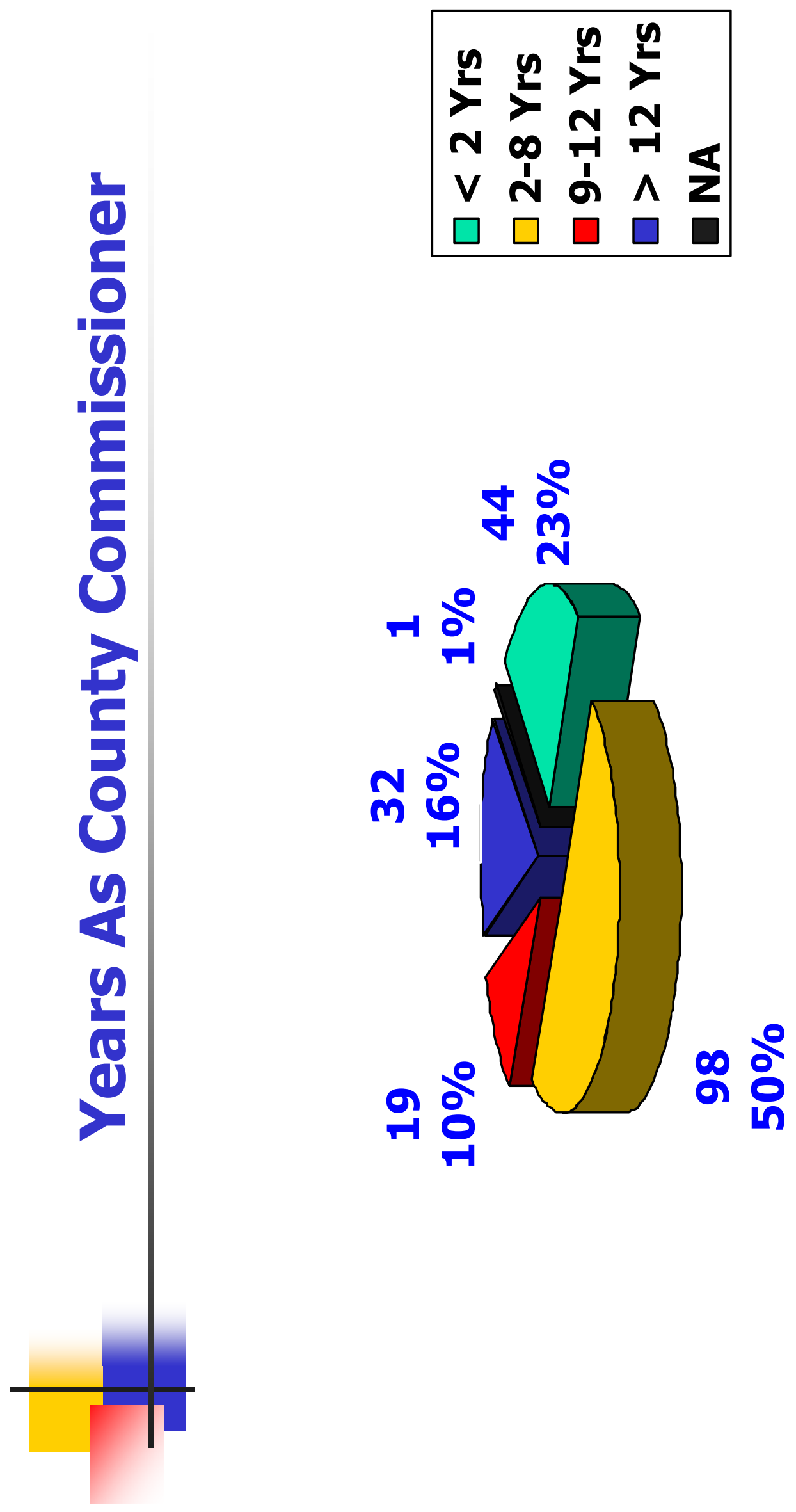

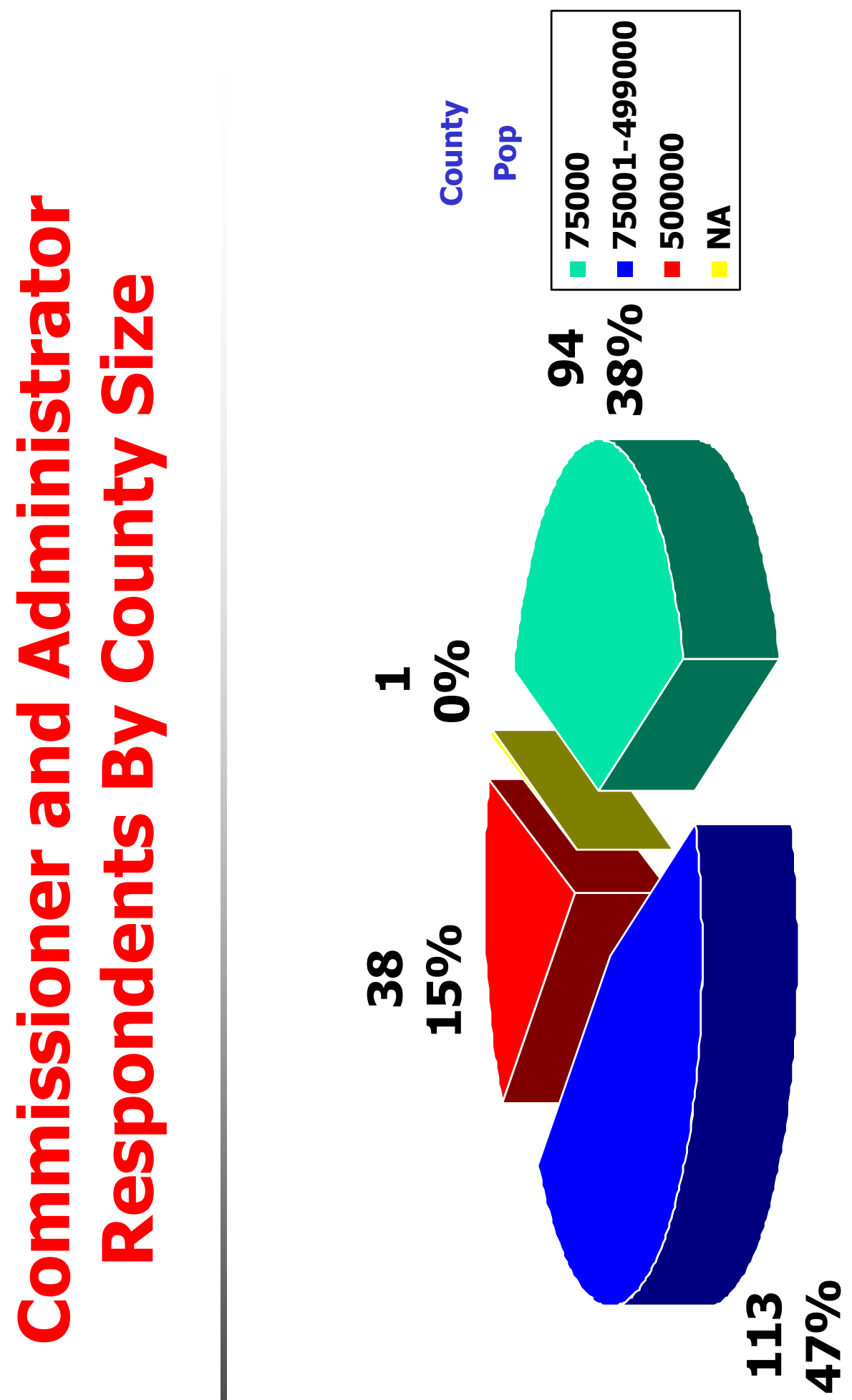


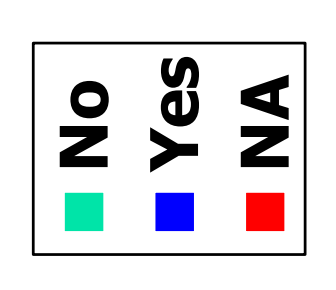

$$
\text { â } \frac{\stackrel{0}{1}}{\text { in }}
$$

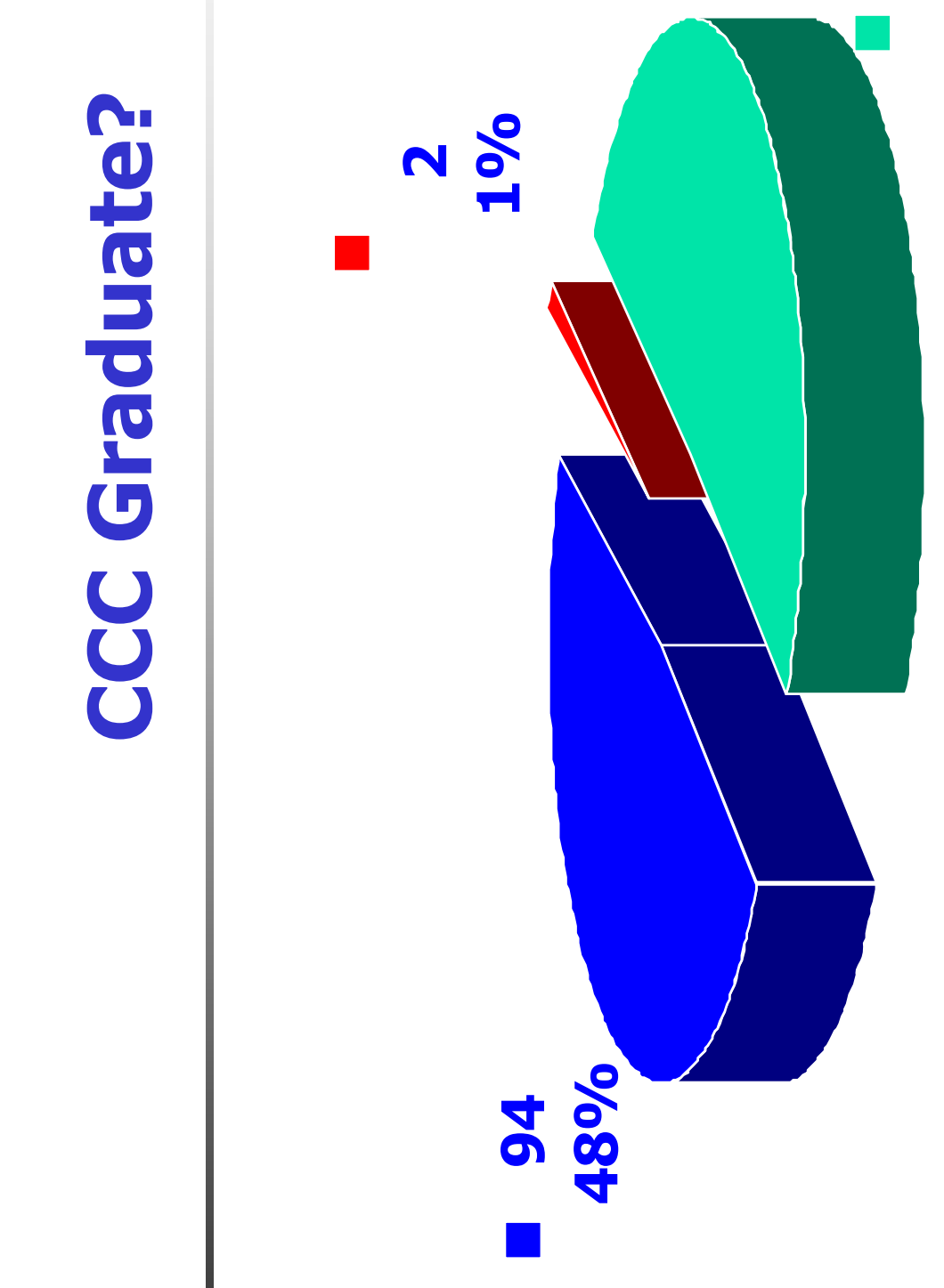



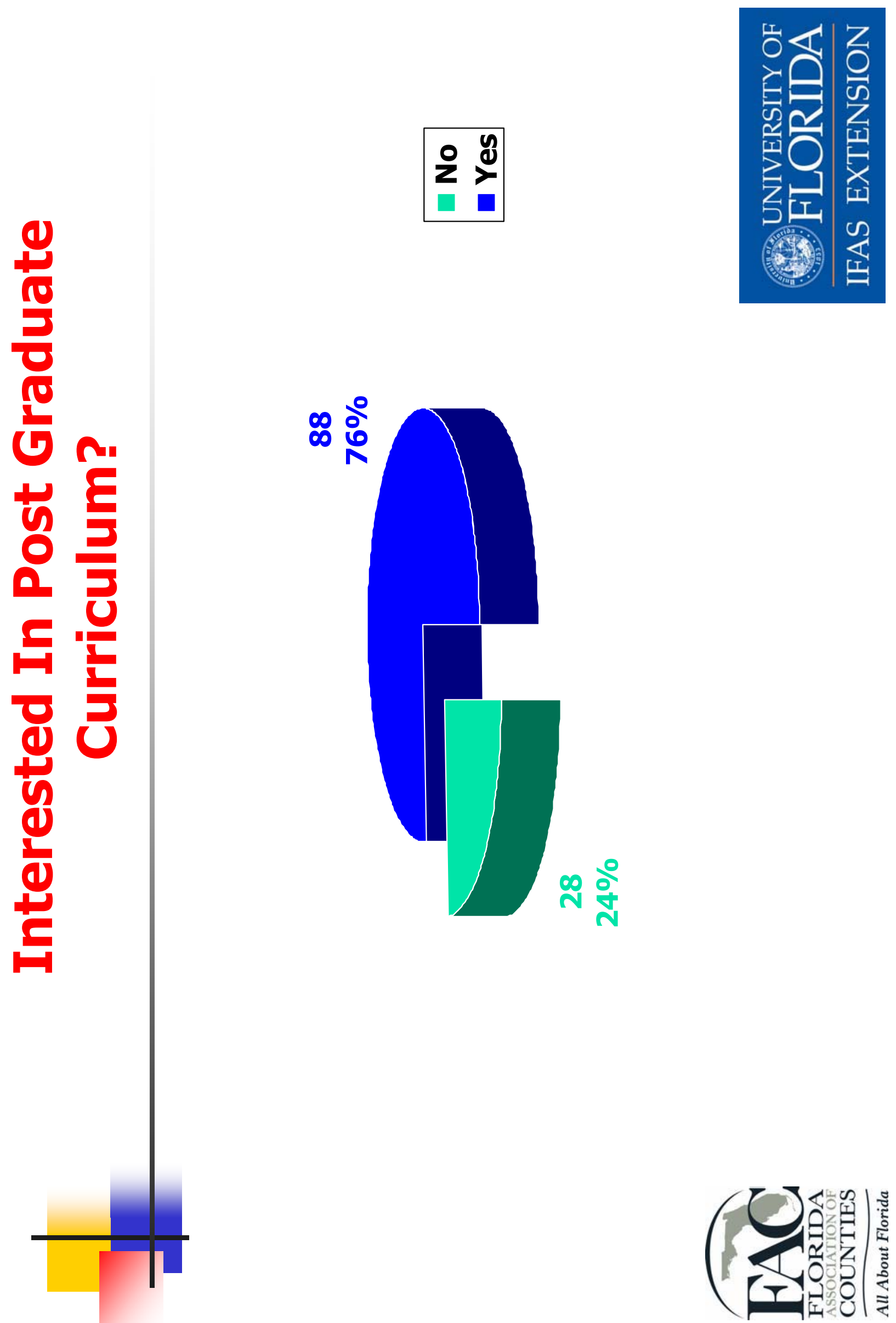

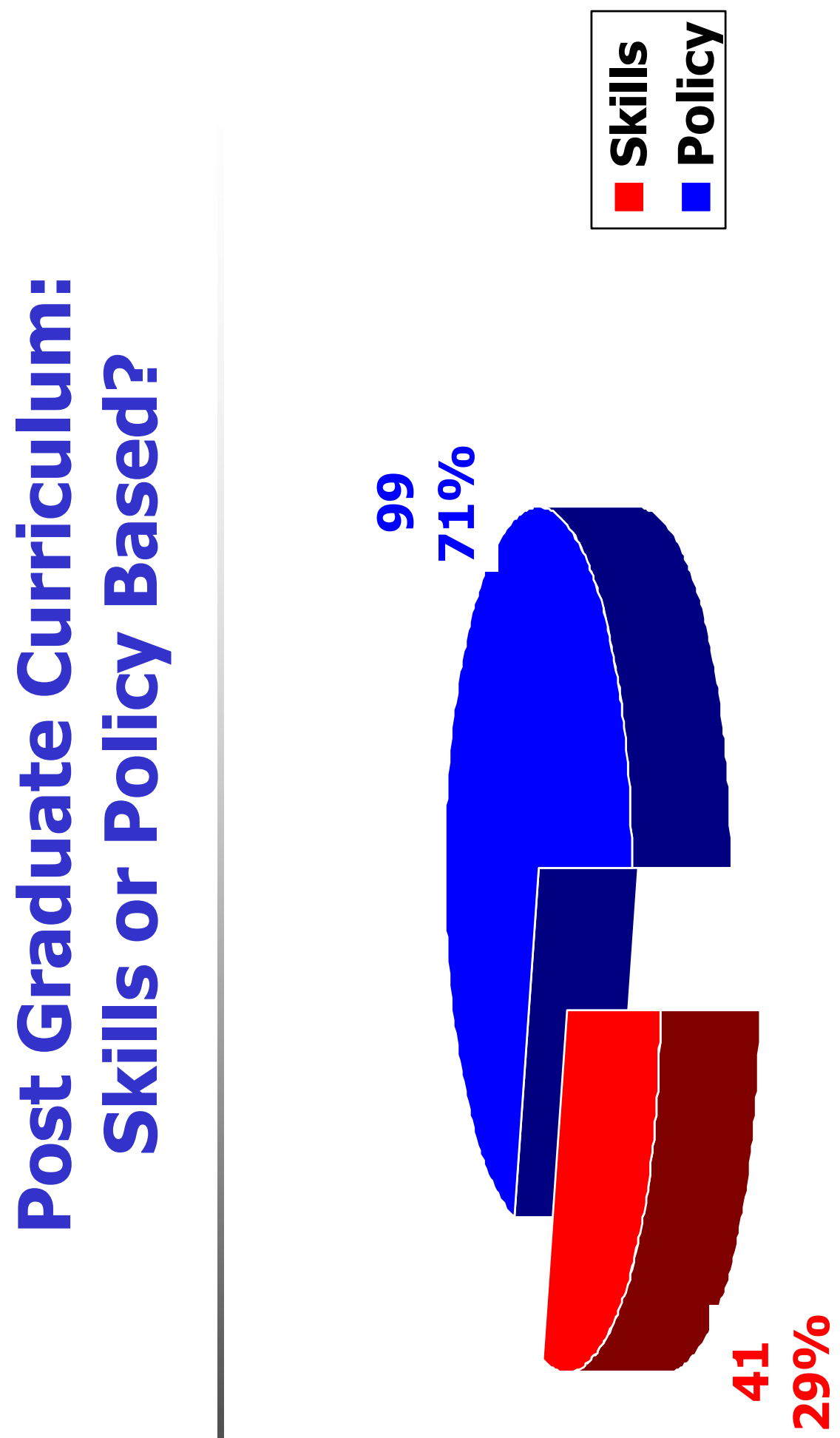

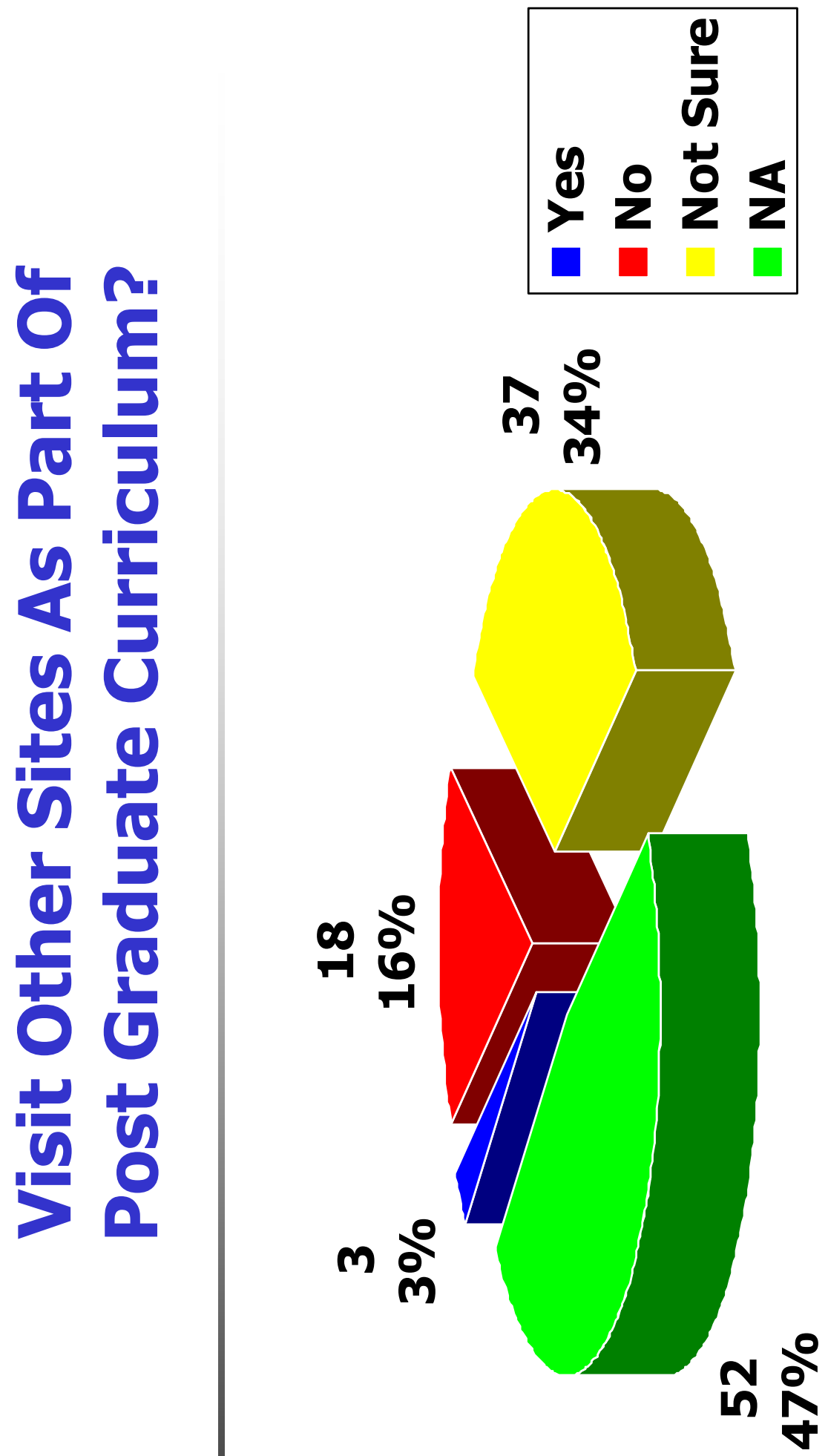

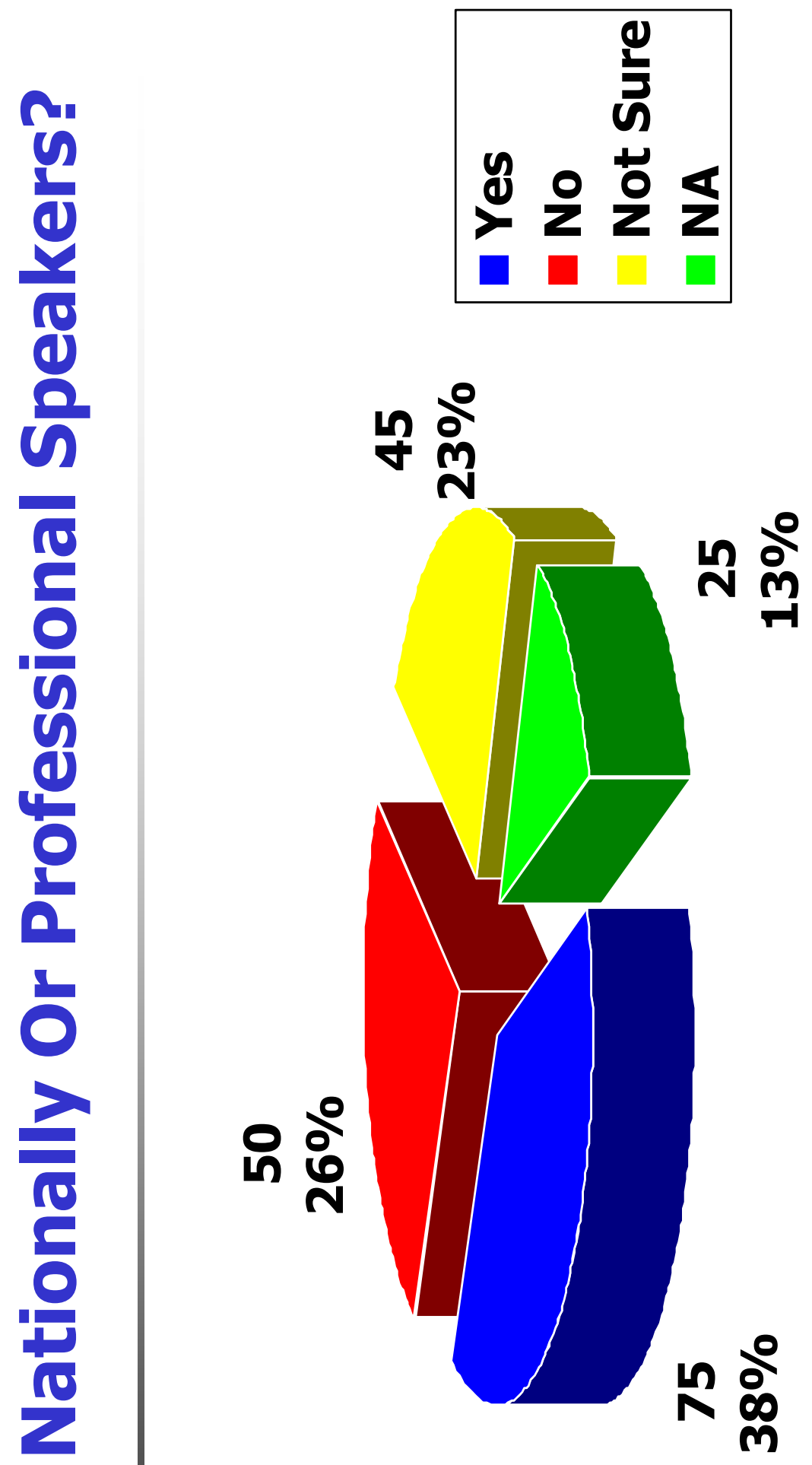


$$
\text { है }
$$

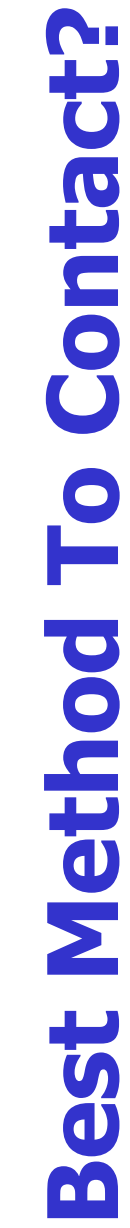

$+\frac{0}{6}$

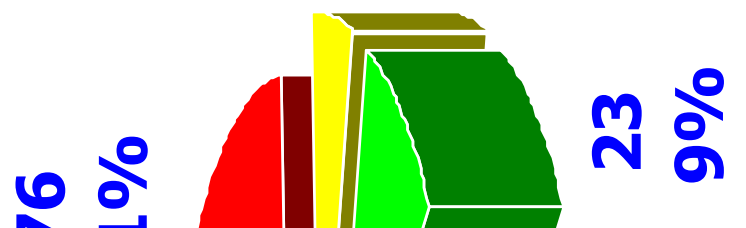

12

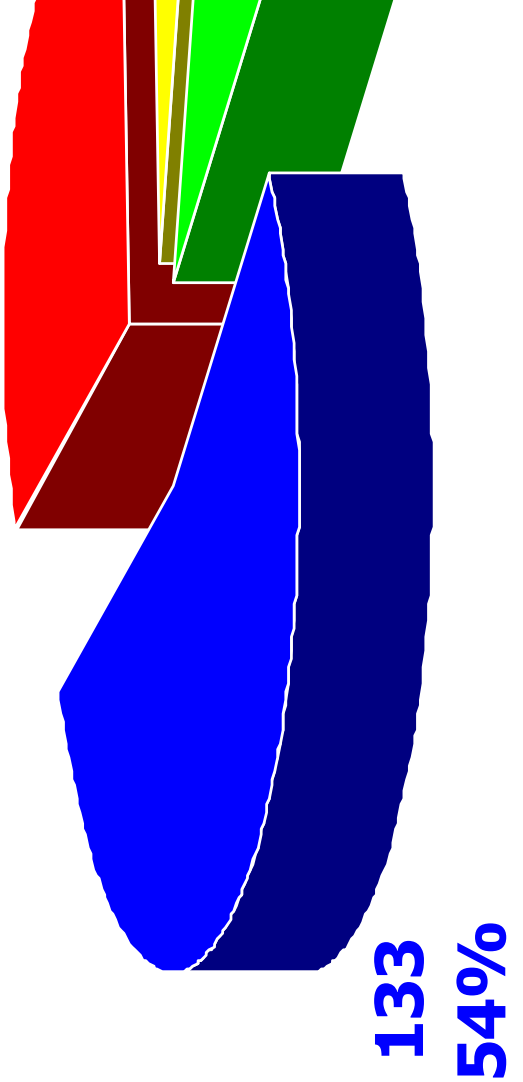




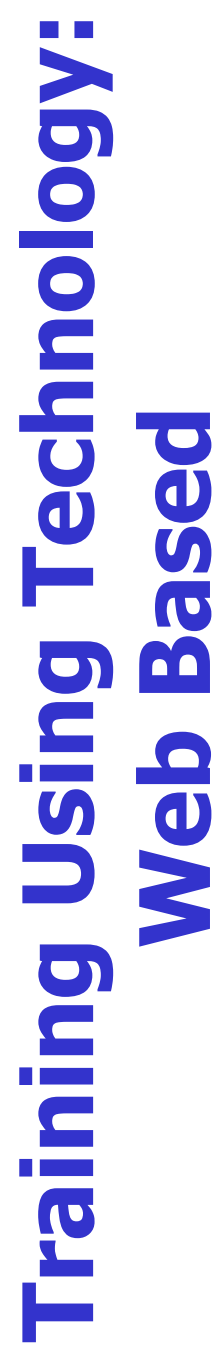

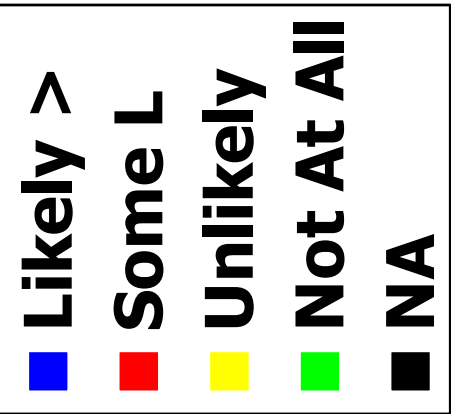

M $\stackrel{0}{\circ}$

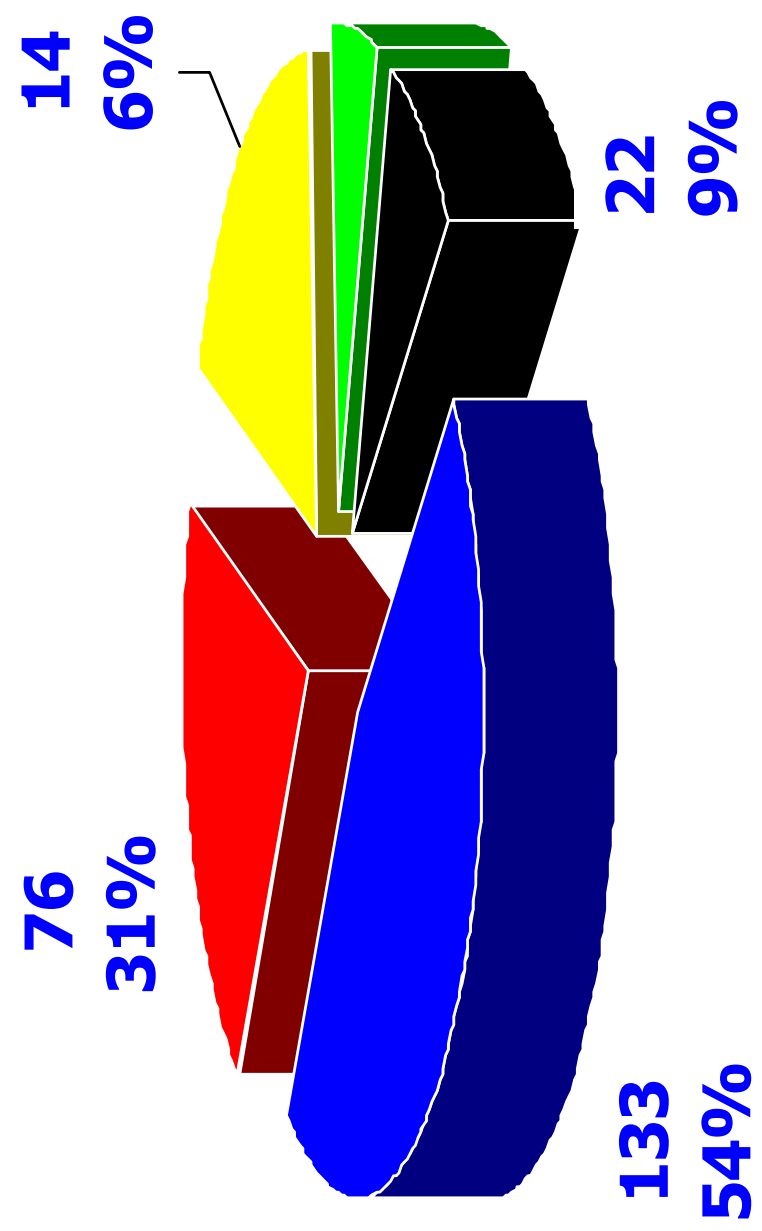




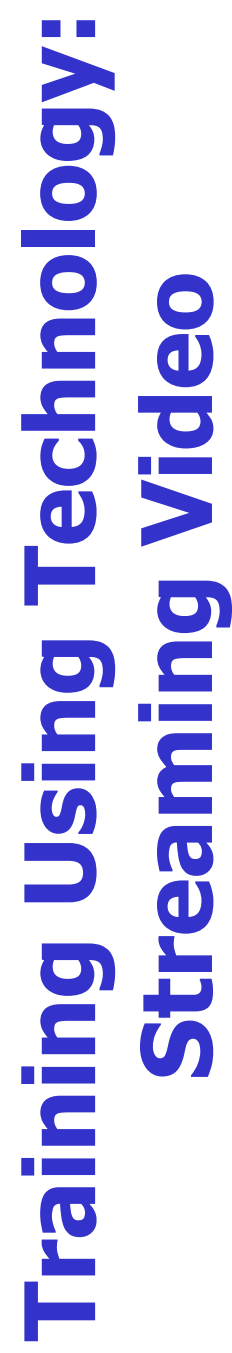

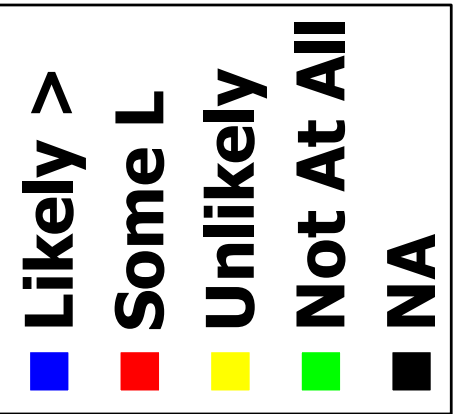

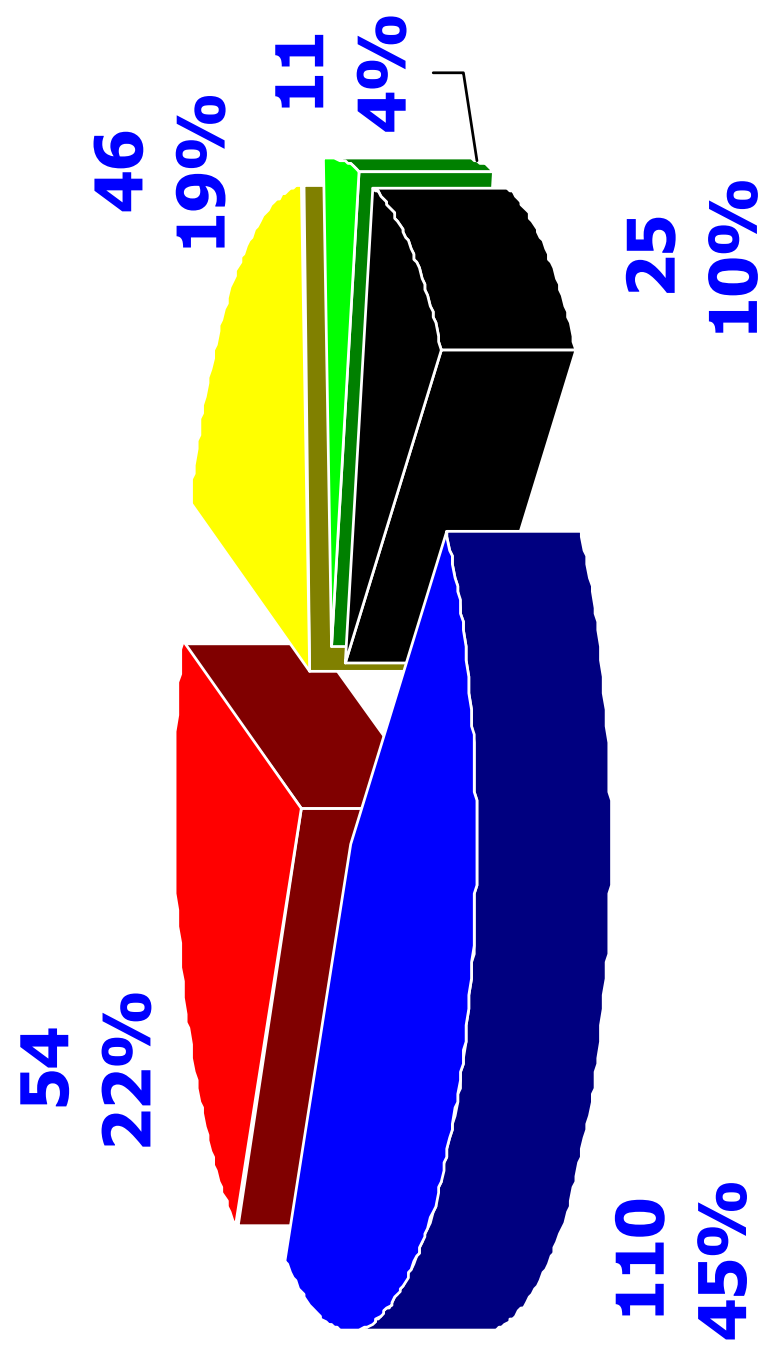




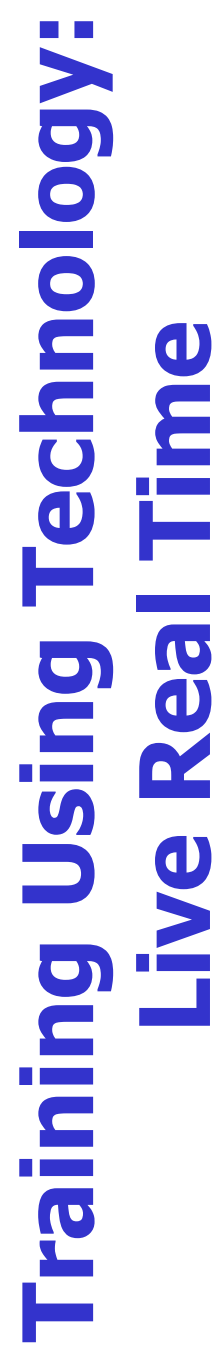

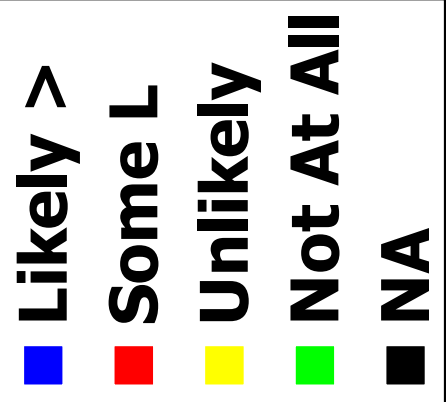

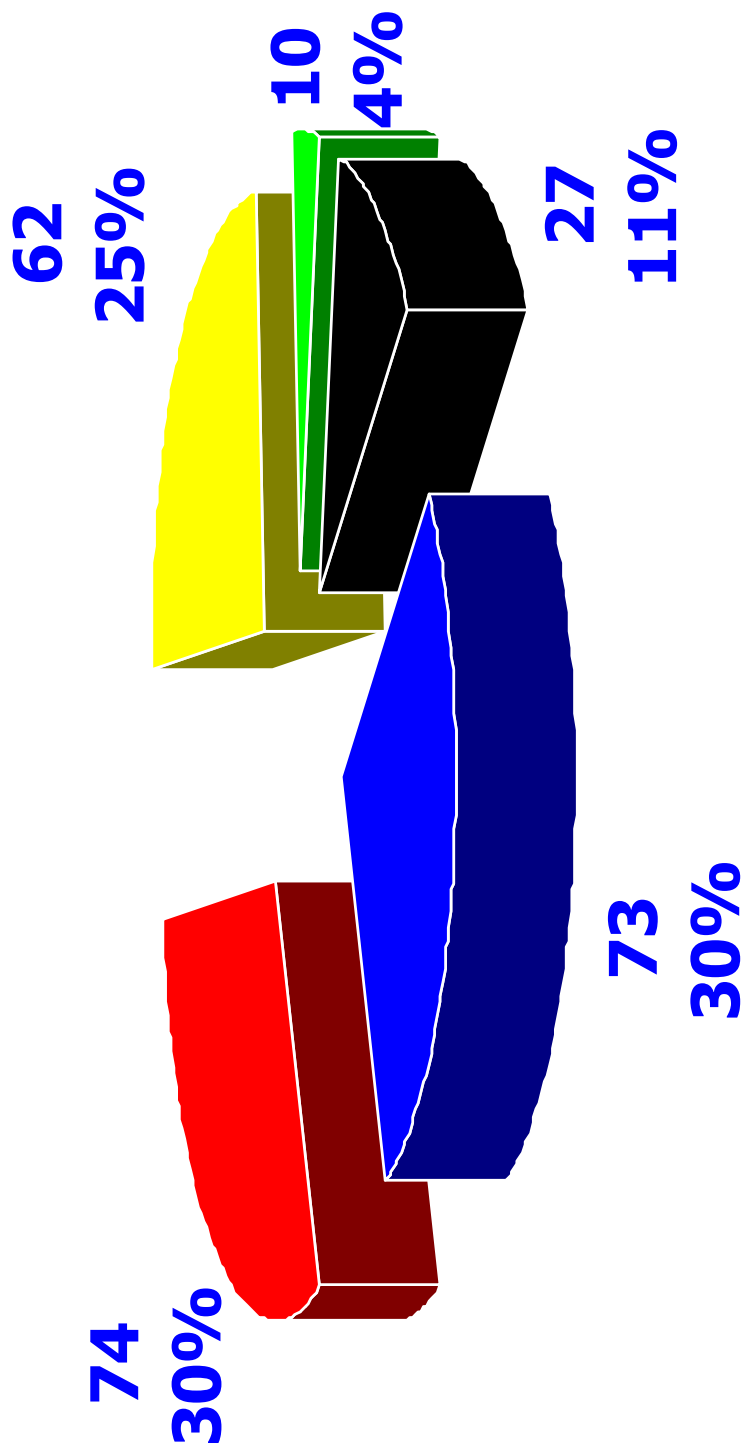




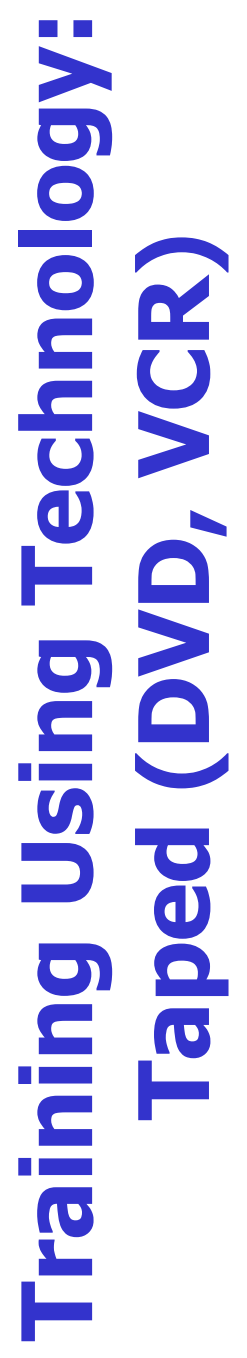

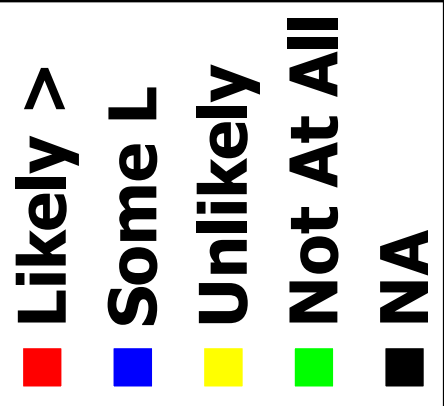

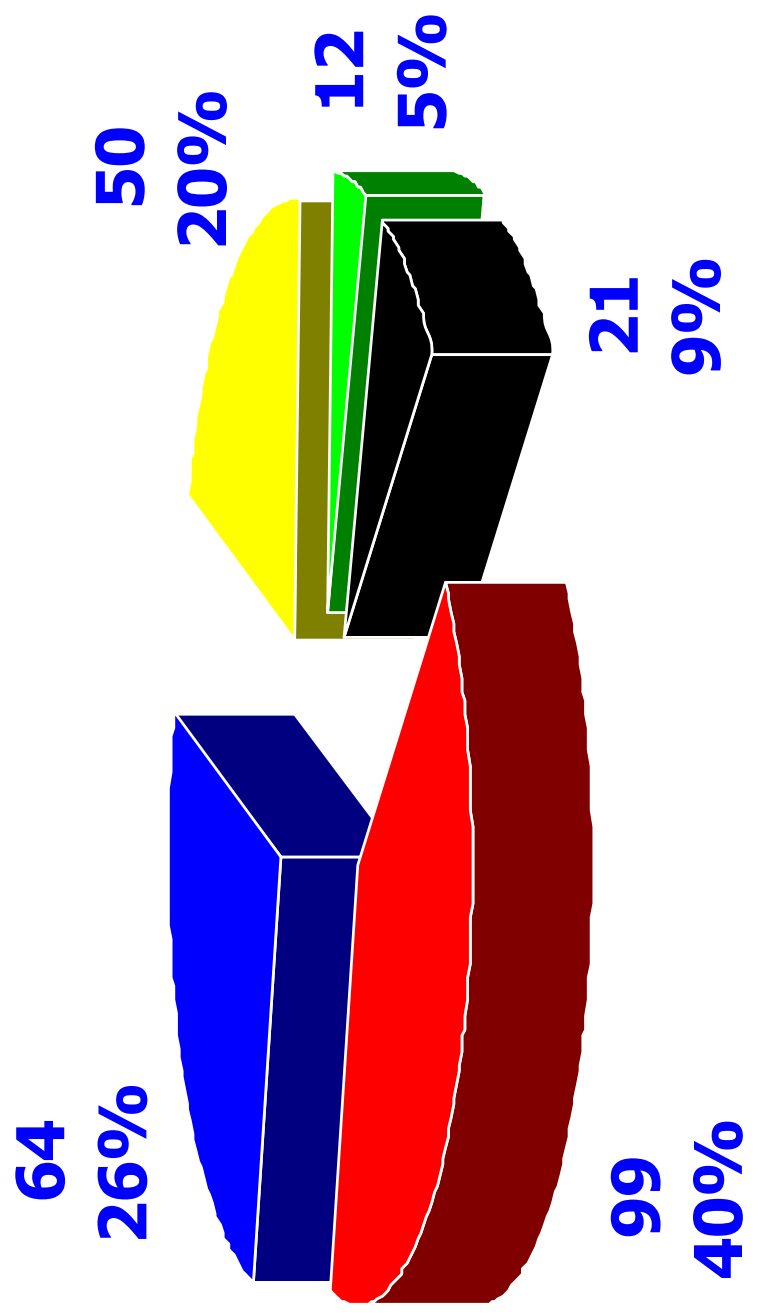




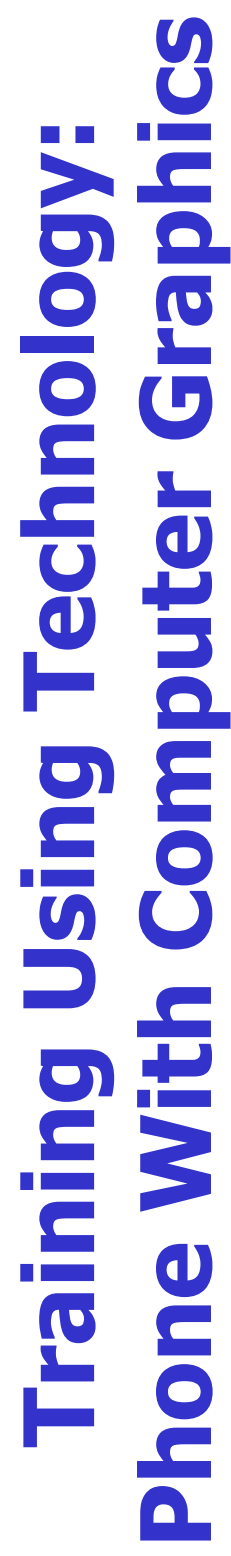

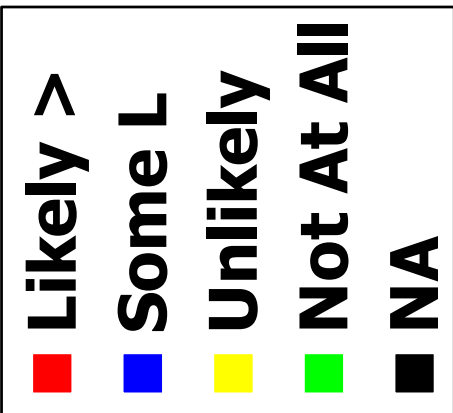
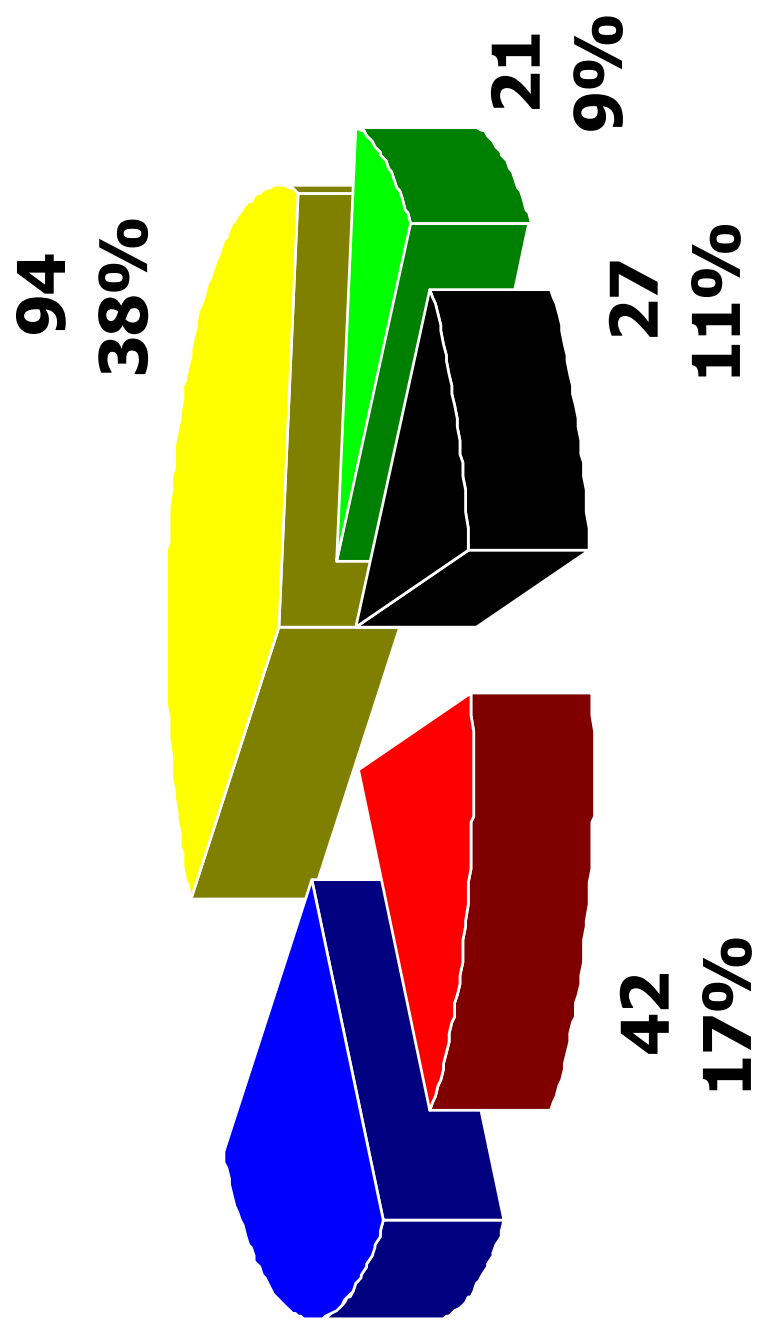

$6{ }^{\circ}$ 

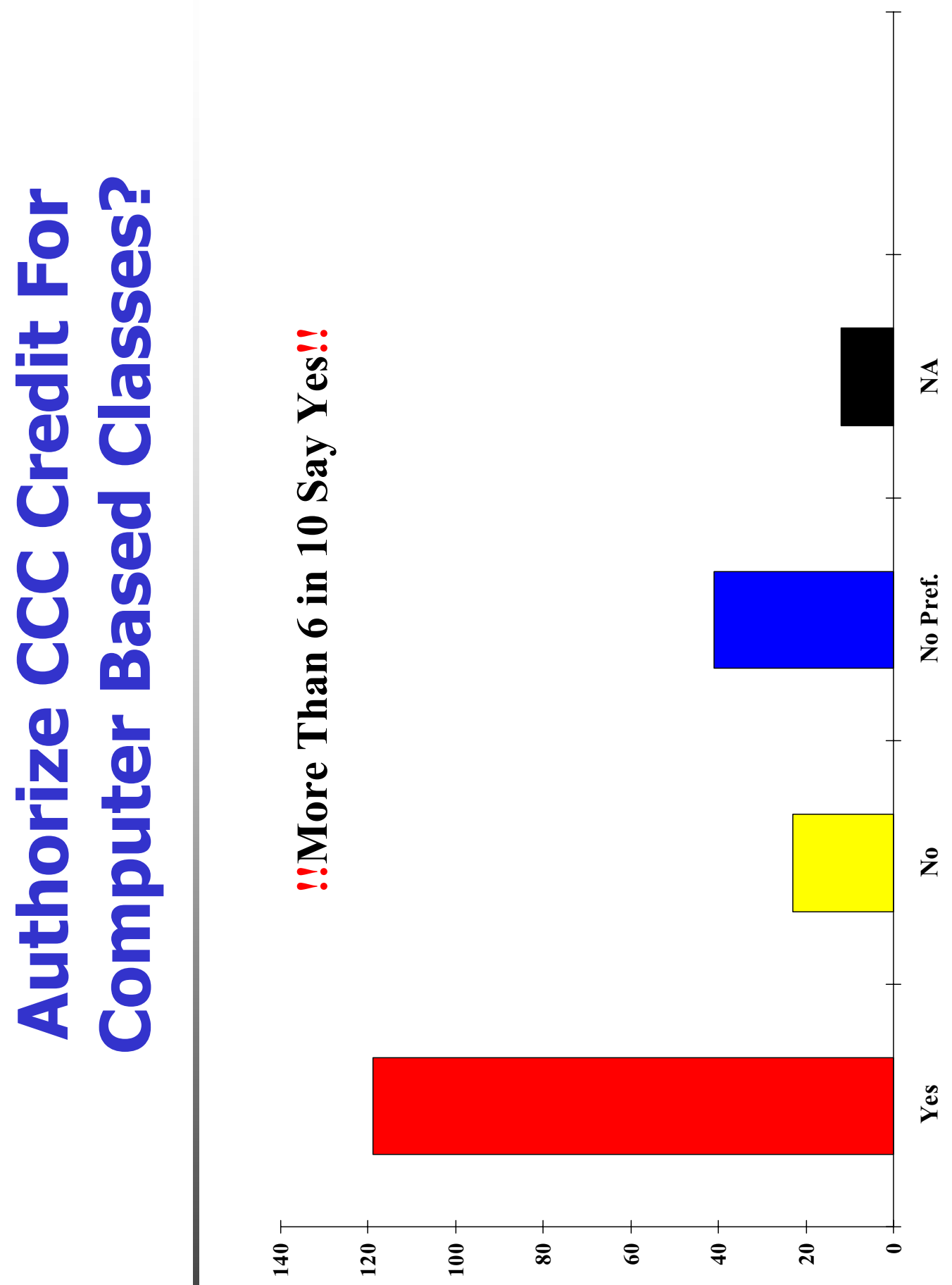

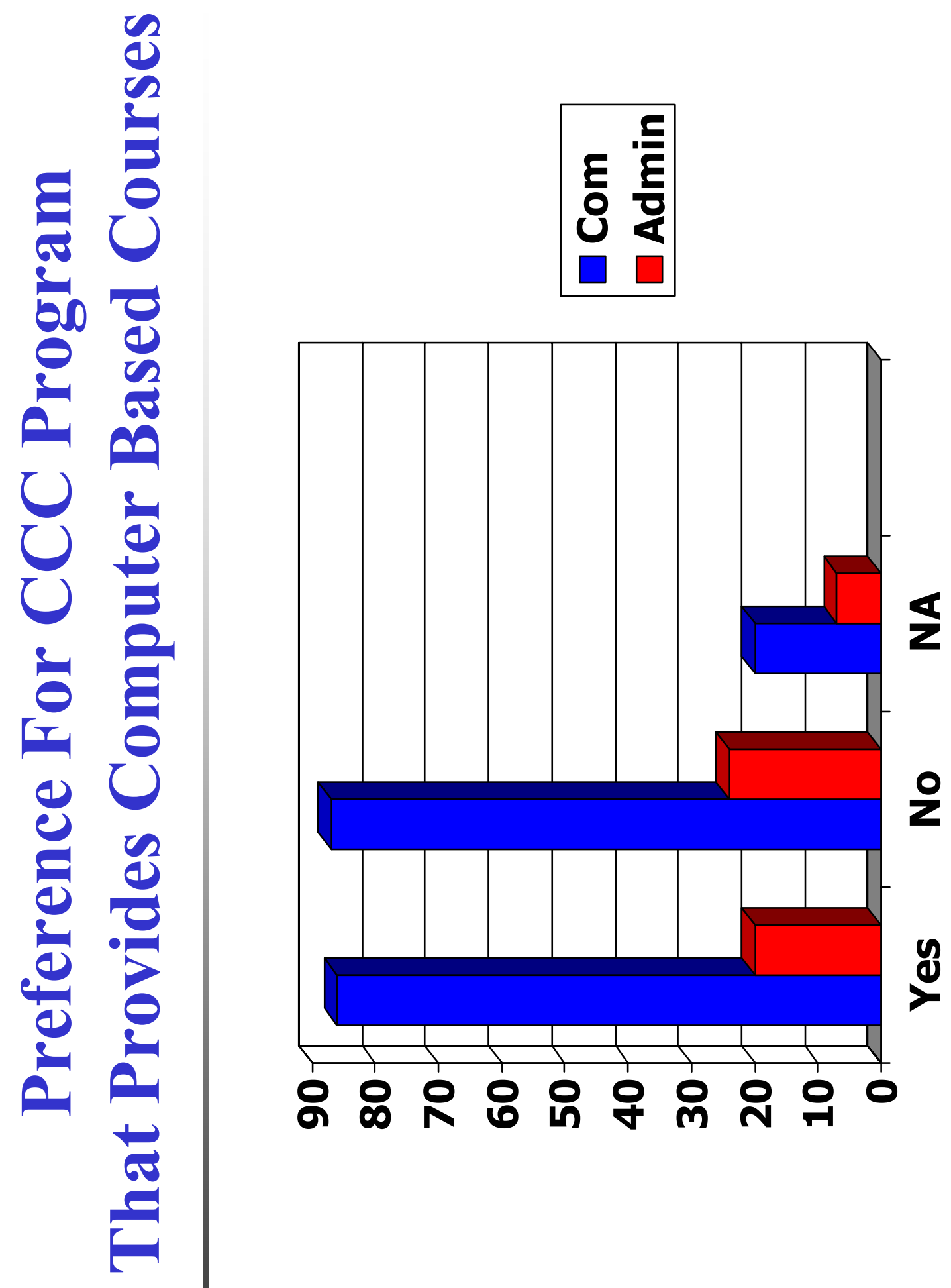


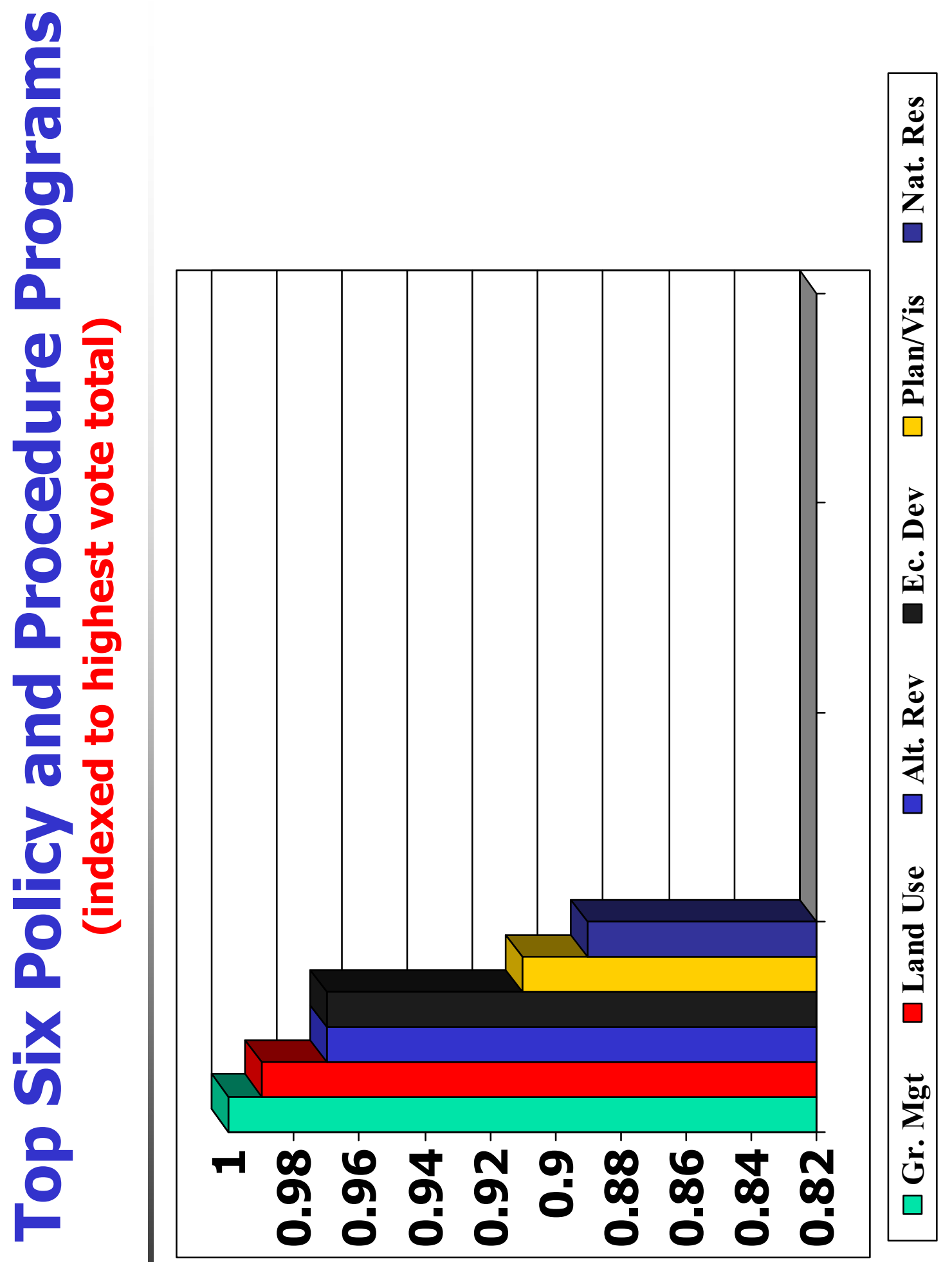




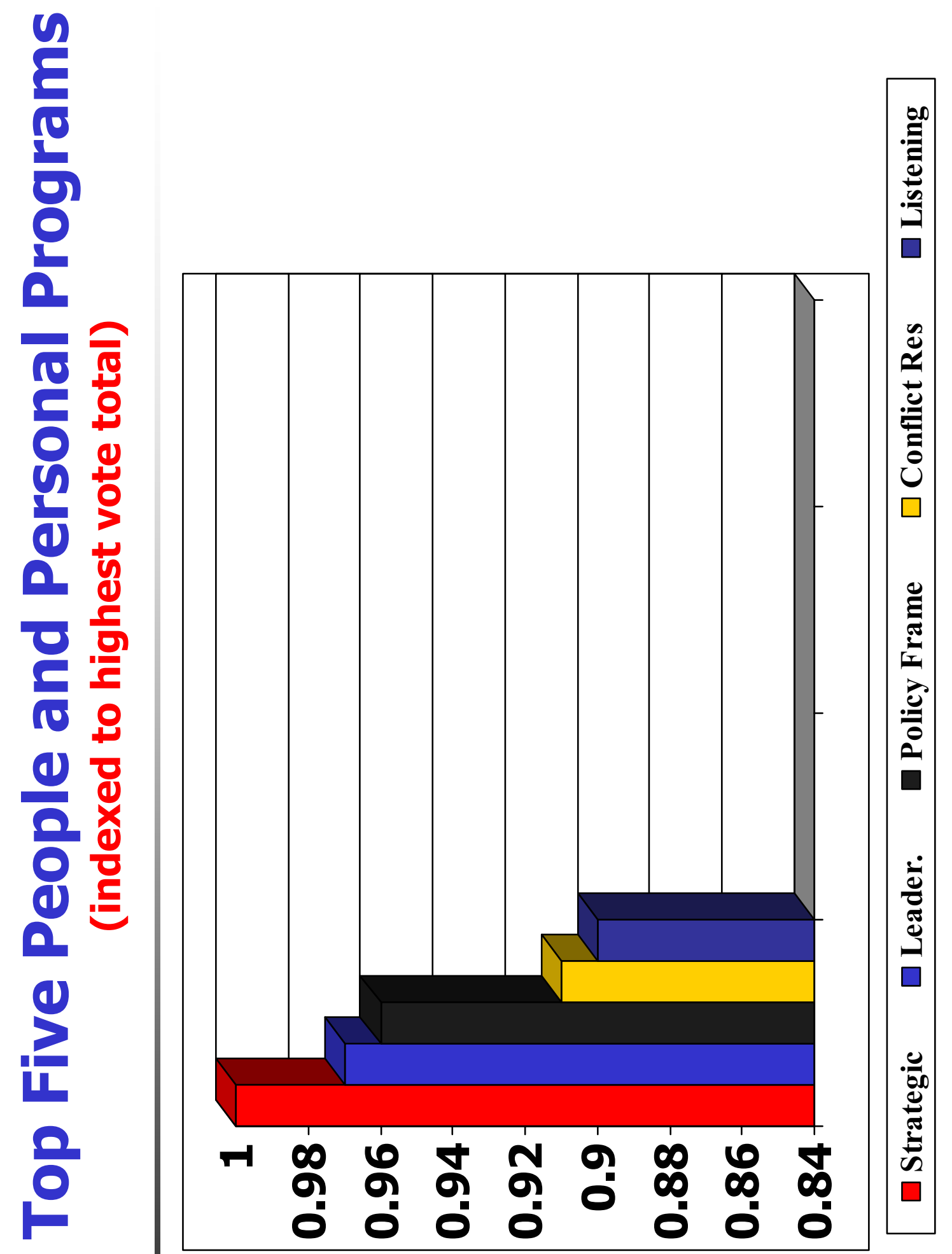




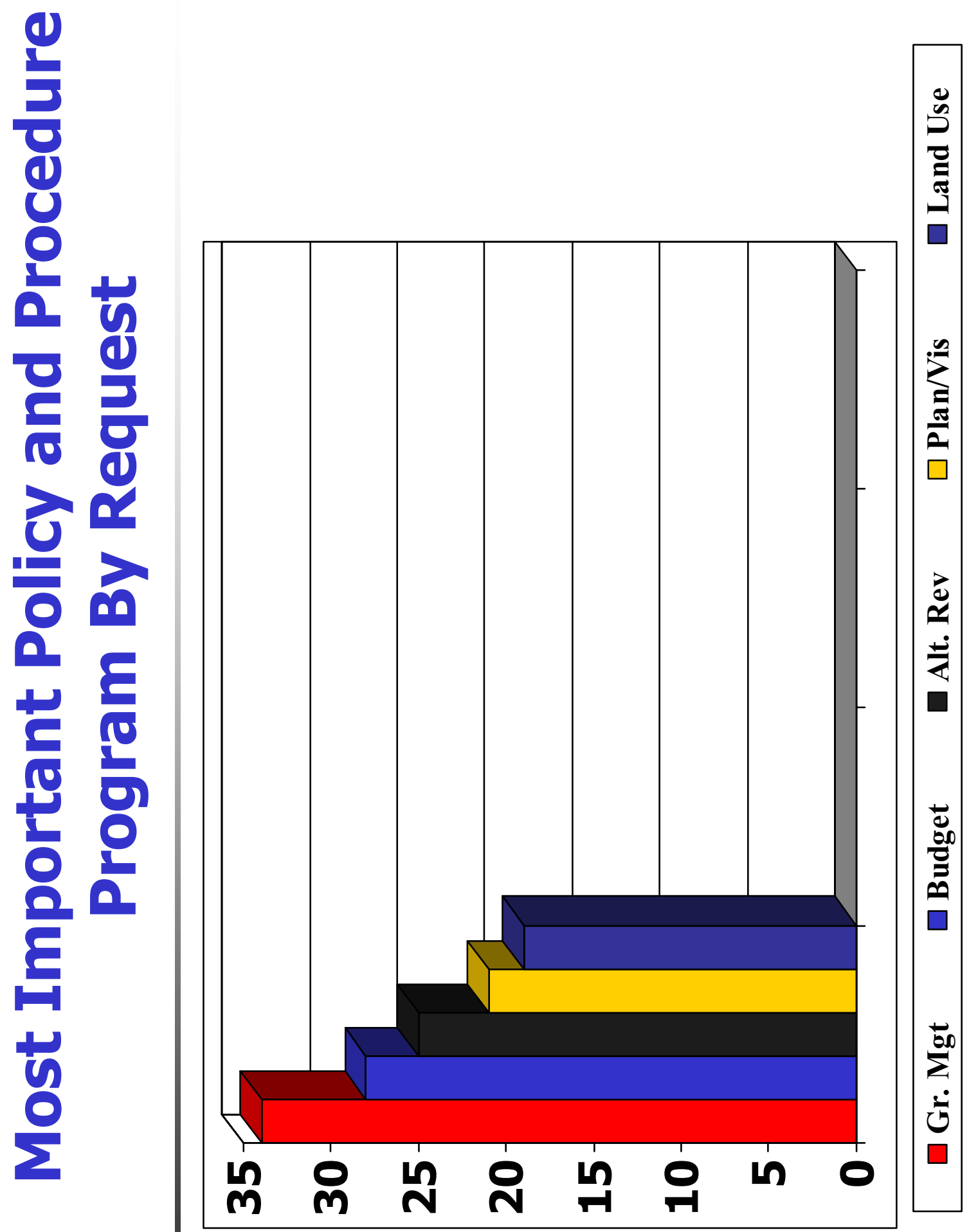




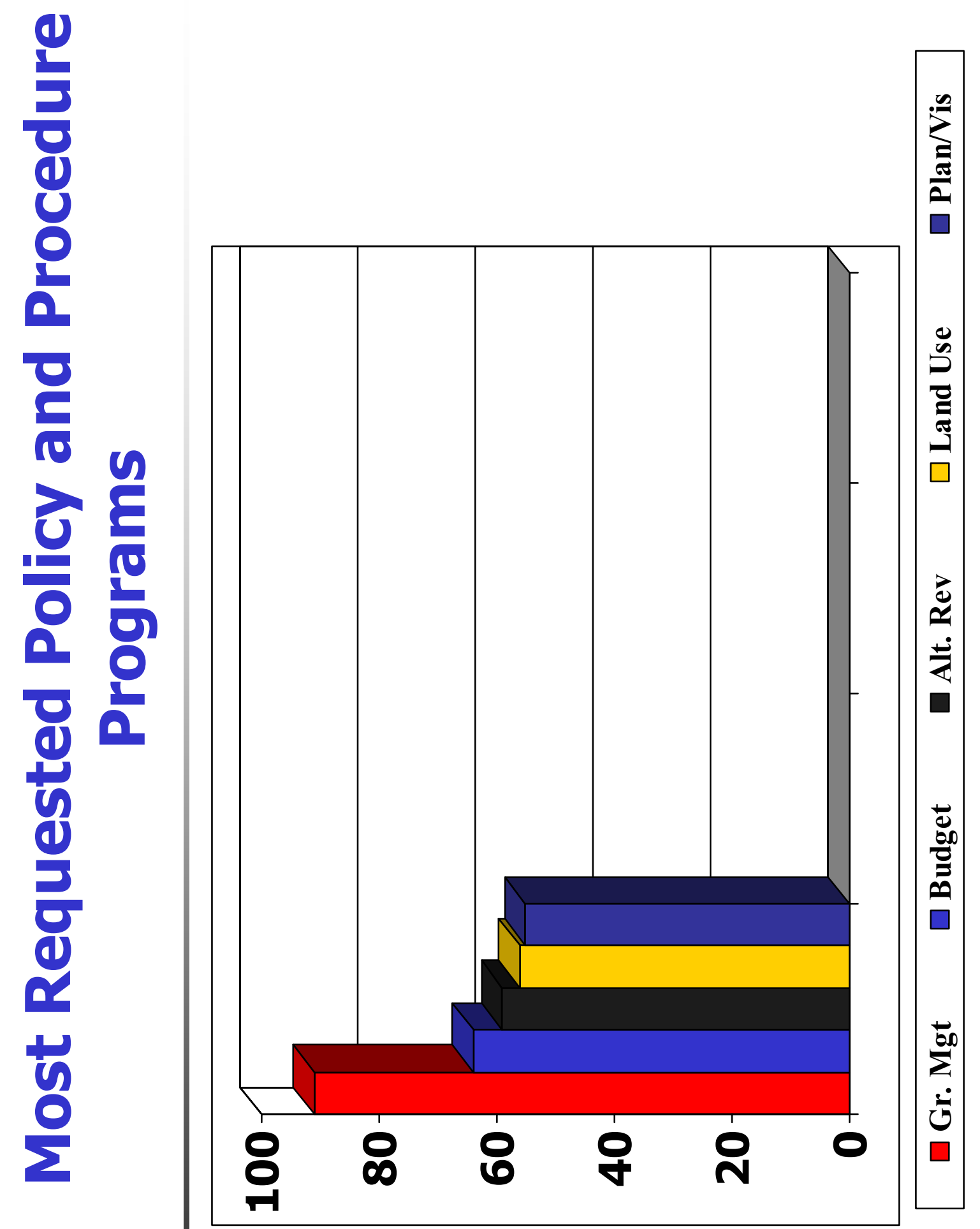




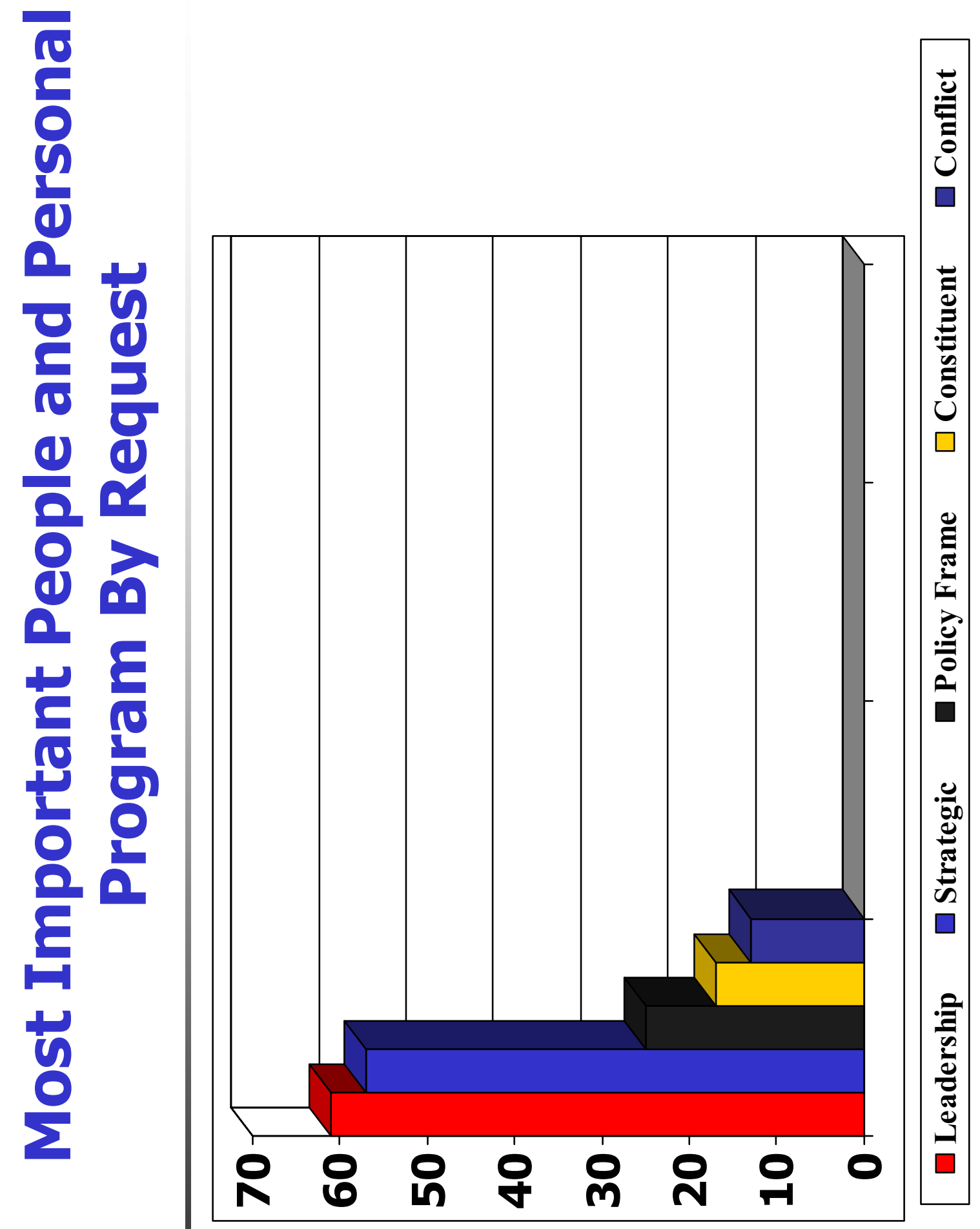




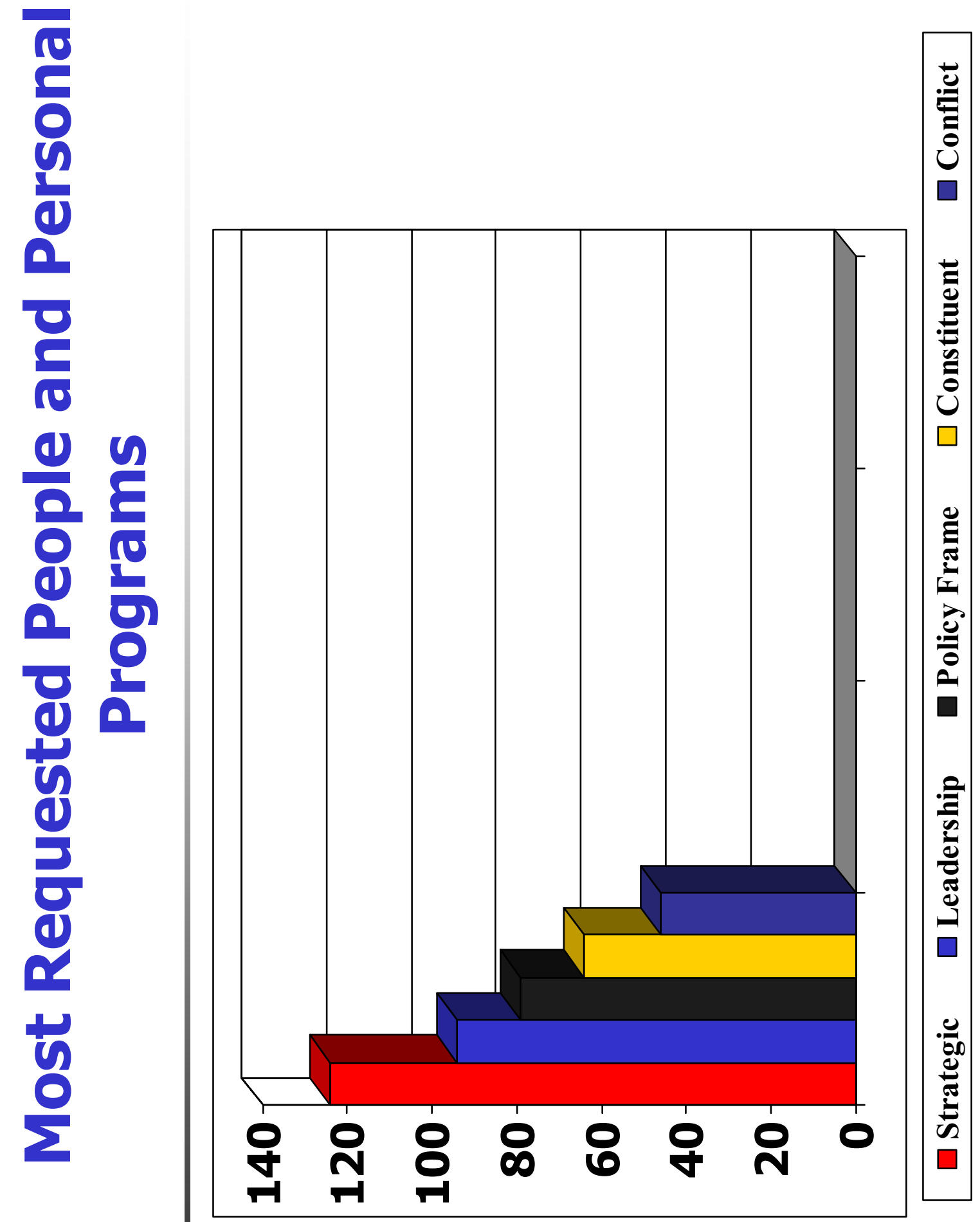




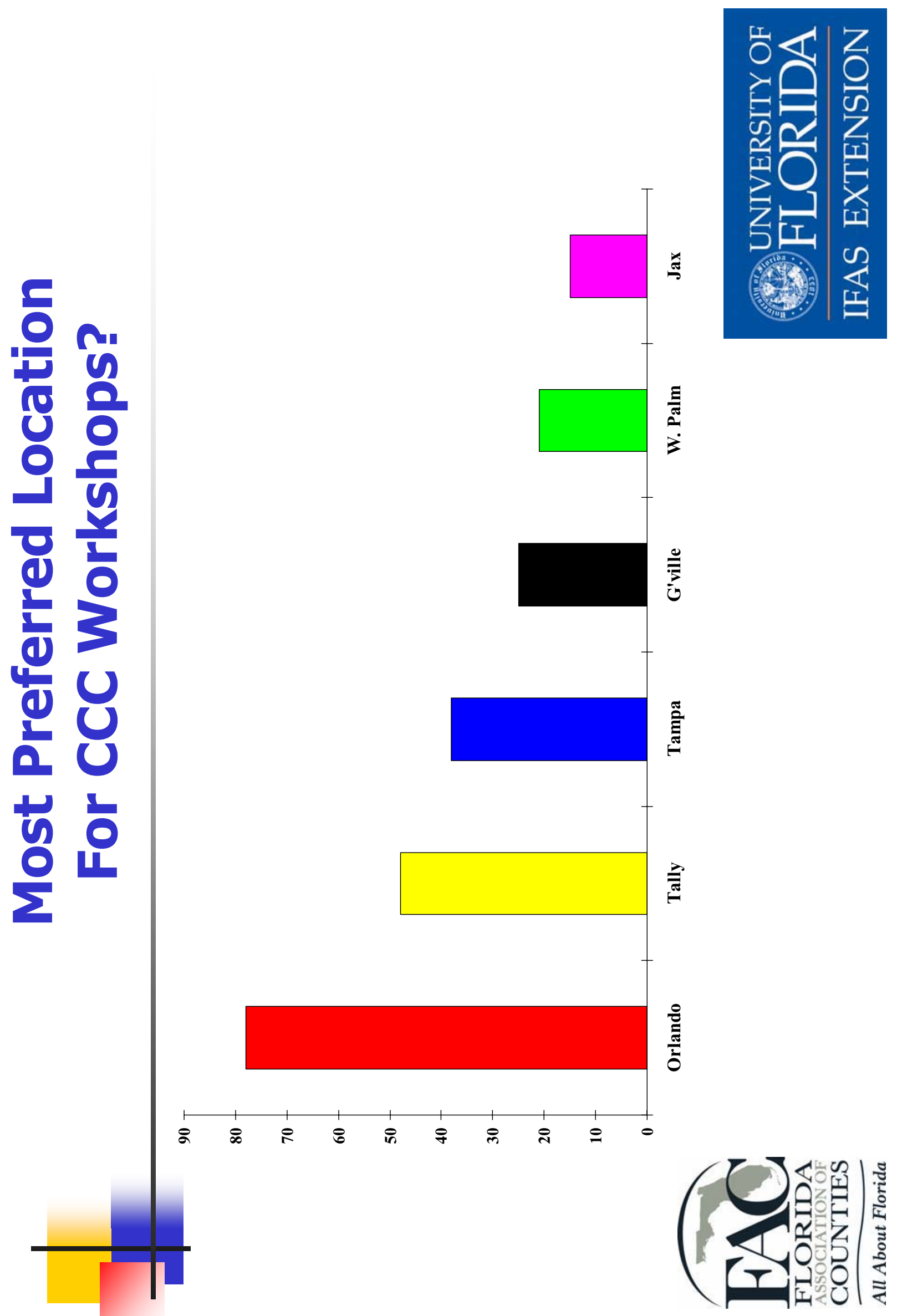

